\title{
ONREL
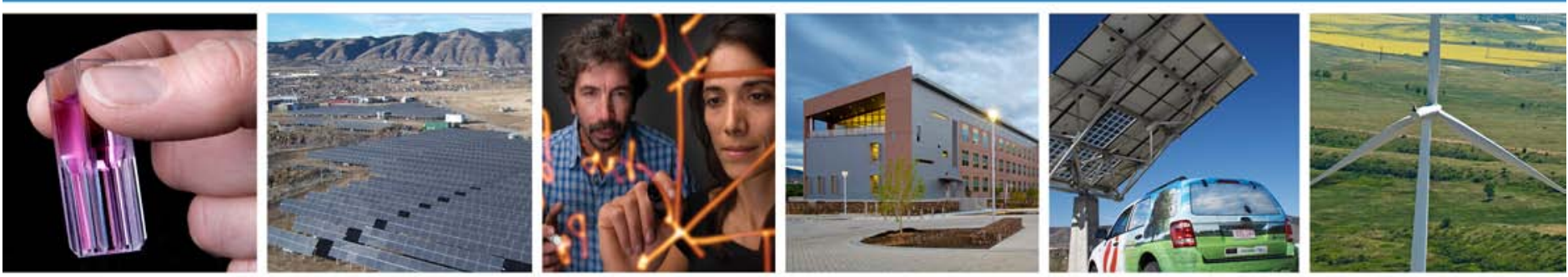

\section{Guide for Identifying and Converting High-Potential Petroleum Brownfield Sites to Alternative Fuel Stations}

A Study Prepared in Partnership with the Environmental Protection Agency for the RE-Powering America's Land Initiative: Siting Renewable Energy on Potentially Contaminated Land and Mine Sites

Caley Johnson and Dylan Hettinger

Gail Mosey, Project Manager

NREL is a national laboratory of the U.S. Department of Energy, Office of Energy Efficiency \& Renewable Energy, operated by the Alliance for Sustainable Energy, LLC.

Technical Report

NREL/TP-6A20-50898

May 2011 


\section{Guide for Identifying and Converting High-Potential Petroleum Brownfield Sites to Alternative Fuel Stations}

\section{A Study Prepared in Partnership with the Environmental Protection Agency for the RE-Powering America's Land Initiative: Siting Renewable Energy on Potentially Contaminated Land and Mine Sites}

Caley Johnson and Dylan Hettinger

Gail Mosey, Project Manager

Prepared under Task No. WFD6.1001 


\section{NOTICE}

This report was prepared as an account of work sponsored by an agency of the United States government. Neither the United States government nor any agency thereof, nor any of their employees, makes any warranty, express or implied, or assumes any legal liability or responsibility for the accuracy, completeness, or usefulness of any information, apparatus, product, or process disclosed, or represents that its use would not infringe privately owned rights. Reference herein to any specific commercial product, process, or service by trade name, trademark, manufacturer, or otherwise does not necessarily constitute or imply its endorsement, recommendation, or favoring by the United States government or any agency thereof. The views and opinions of authors expressed herein do not necessarily state or reflect those of the United States government or any agency thereof.

Available electronically at http://www.osti.gov/bridge

Available for a processing fee to U.S. Department of Energy and its contractors, in paper, from:

U.S. Department of Energy

Office of Scientific and Technical Information

P.O. Box 62

Oak Ridge, TN 37831-0062

phone: 865.576.8401

fax: 865.576 .5728

email: mailto:reports@adonis.osti.gov

Available for sale to the public, in paper, from:

U.S. Department of Commerce

National Technical Information Service

5285 Port Royal Road

Springfield, VA 22161

phone: 800.553 .6847

fax: 703.605.6900

email: orders@ntis.fedworld.gov

online ordering: http://www.ntis.gov/help/ordermethods.aspx

Cover Photos: (left to right) PIX 16416, PIX 17423, PIX 16560, PIX 17613, PIX 17436, PIX 17721

Printed on paper containing at least $50 \%$ wastepaper, including $10 \%$ post consumer waste. 


\section{Acknowledgments}

This work was funded by the Environmental Protection Agency's (EPA) RE-Powering America's Land initiative through a partnership with the National Renewable Energy Laboratory (NREL). The authors appreciate the leadership of this partnership provided by Lura Matthews (with EPA's Office of Solid Waste and Emergency Response) and Gail Mosey (NREL). The authors are particularly thankful for the guidance and technical expertise of Deb Steckley (EPA's Office of Underground Storage Tanks). 


\section{Executive Summary}

Former gasoline stations that are now classified as brownfields can be good sites to sell alternative fuels because they are in locations that are convenient to vehicles and they may be seeking a new source of income. However, their success as alternative fueling stations is highly dependent on location-specific criteria. First, this report outlines what these criteria are, how to prioritize them, and then applies that assessment framework to five of the most popular alternative fuels - electricity, natural gas, hydrogen, ethanol, and biodiesel. The corridor between San Francisco and Los Angeles, California, is found to be exceptional for all five fuels; the corridor between Seattle, Washington, and Eugene, Oregon, is exceptional for electricity, natural gas, ethanol, and biodiesel; and the Chicago-Milwaukee area is exceptional for natural gas, ethanol, and biodiesel. Multiple locations are found to be promising opportunities to sell two or one alternative fuels.

The second part of this report delves into the criteria and tools used to assess an alternative fuel retail site at the local level. It does this through two case studies of converting former gasoline stations in the Seattle-Eugene area into electric charge stations. Four tools used for this assessment were: (1) an NREL map of existing infrastructure, hybrid electric vehicles (HEVs), and leaking underground storage tank (LUST) sites; (2) state databases of LUSTs and their attributes; (3) the alternative fuel station locator at the DOE's Alternative Fuel and Advanced Vehicles Data Center ${ }^{1}$; and (4) the Google Maps "search nearby" function to find nearby sites that can keep people occupied while they wait for their vehicle to recharge. These four tools enable the site owner to judge their site based on 12 criteria that are available at the local level.

The third part of this report addresses steps to be taken after the specific site has been selected. This includes choosing and installing the recharging equipment, which includes steps to take in the permitting process and key players to include.

${ }^{1}$ U.S. Department of Energy. “Alternative Fuels \& Advanced Vehicles Data Center.” www.afdc.energy.gov/afdc/. Accessed April 2011. 


\section{Tables of Contents}

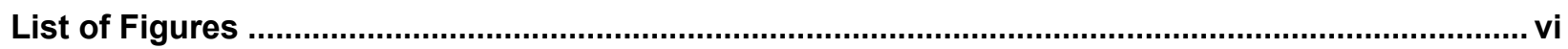

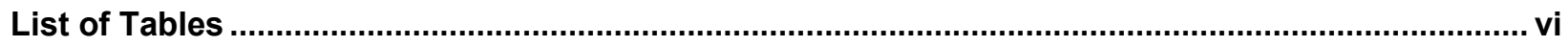

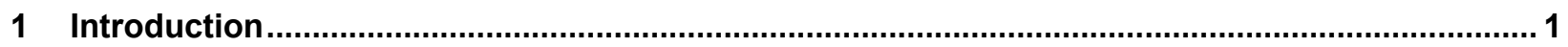

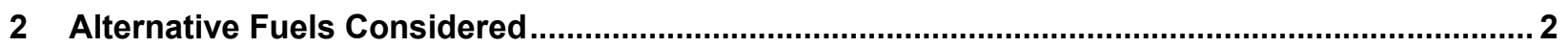

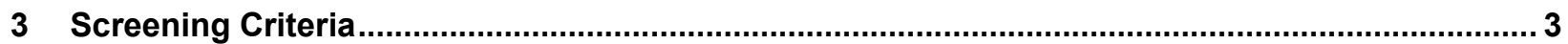

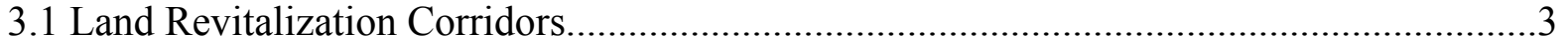

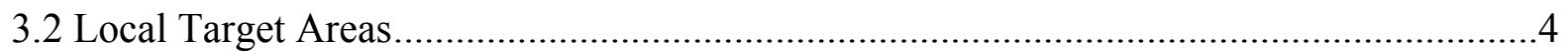

3.3 Existing Infrastructure ........................................................................................

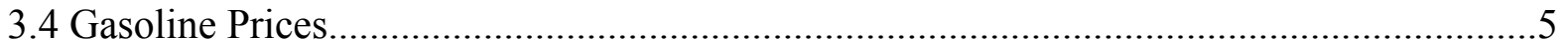

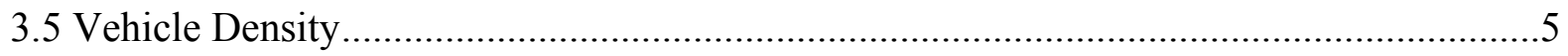

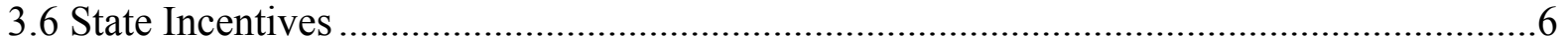

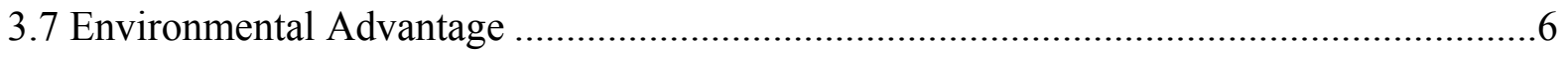

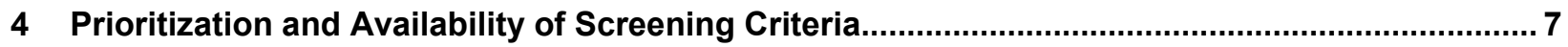

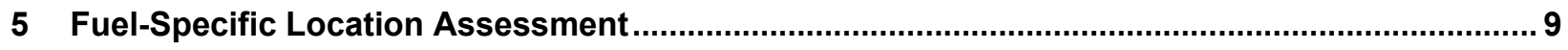

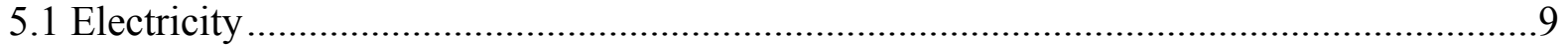

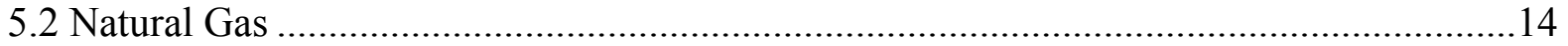

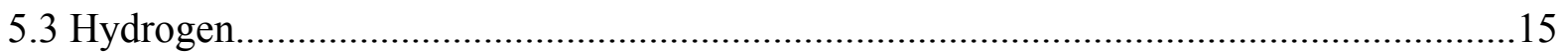

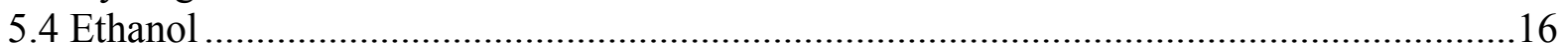

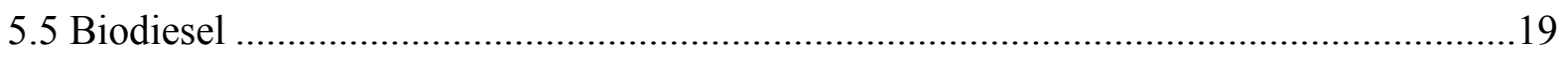

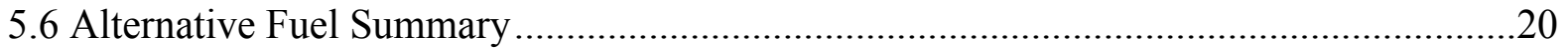

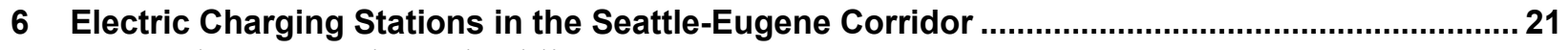

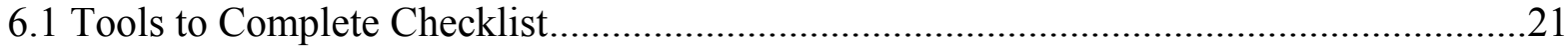

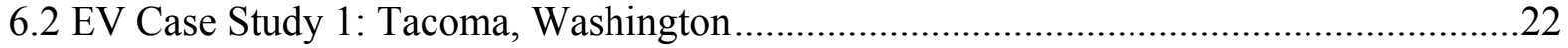

6.3 EV Case Study 2: Heritage Mall in Albany, Oregon...................................................24

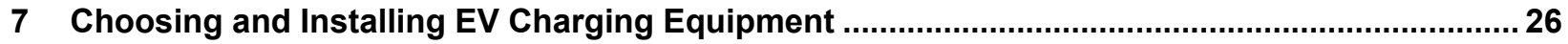

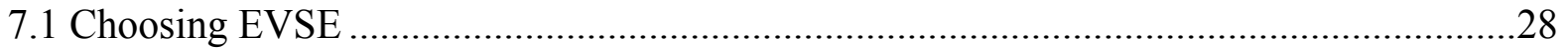

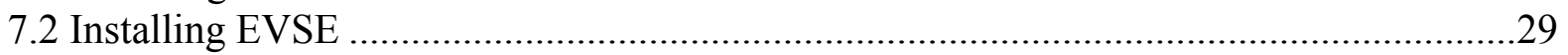

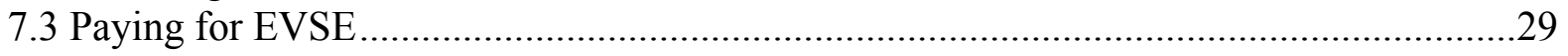

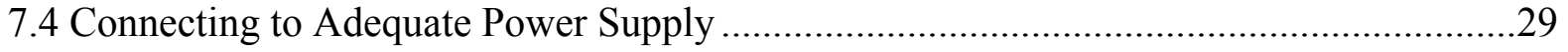

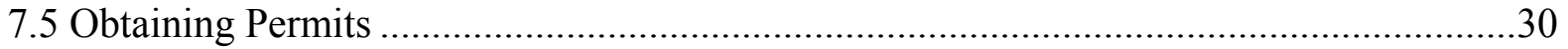

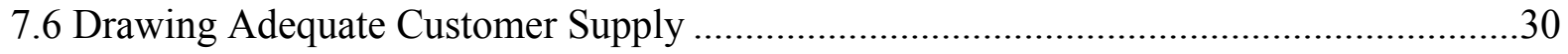

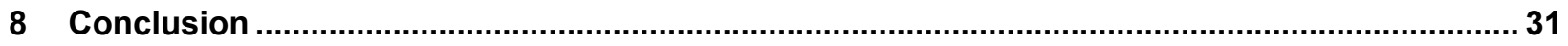




\section{List of Figures}

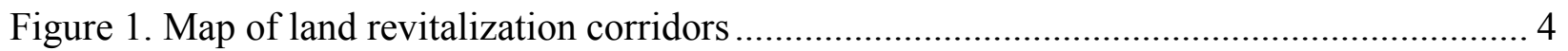

Figure 2. Map of snapshot gasoline prices averaged by county in the United States..................... 5

Figure 3. Land revitalization corridors, EV infrastructure, and the local initiatives and state

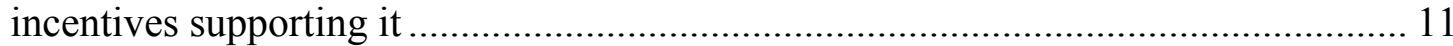

Figure 4. Land revitalization corridors, EV infrastructure, and HEV density by county ............. 12

Figure 5. GHG intensity, land revitalization corridors, and EV infrastructure.............................. 13

Figure 6. Natural gas stations, land revitalization corridors, and pro-natural-gas incentives....... 15

Figure 7. Hydrogen stations, land revitalization corridors, and pro-hydrogen incentives............ 16

Figure 8. E85 stations, land revitalization corridors, and state ethanol incentives ....................... 17

Figure 9. FFV density, E85 stations, and land revitalization corridors ...................................... 18

Figure 10. Biodiesel stations, land revitalization corridors, and state biodiesel incentives.......... 20

Figure 11. LUSTs, HEVs, EV focus sites, and land revitalization corridor along I-5 between

Seattle, Washington, and Eugene, Oregon................................................................. 22

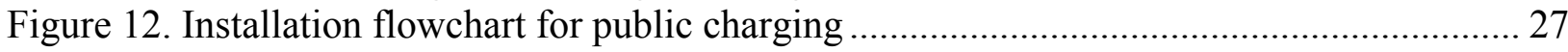

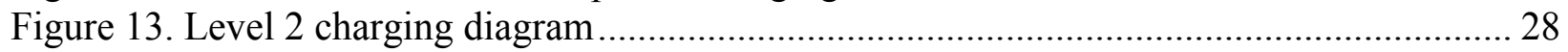

\section{List of Tables}

Table 1. Alternative Transportation Fuels, Vehicle Characteristics, and Deployment Strategy .... 2

Table 2. Land Revitalization Corridors and Locations (Ordered East to West) ............................... 3

Table 3. Screening Criteria for Location Choice, Weighting, and Data Availability ...................... 7

Table 4. Local Initiatives to Install EV Charging Infrastructure .................................................. 9

Table 5. Prioritization of Regions for EV Infrastructure According to Seven Major Criteria ..... 13

Table 6. Multi-Criteria Prioritization of Potential Ethanol Regions ............................................. 19

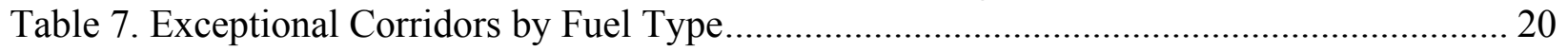




\section{Introduction}

Thousands of gasoline stations have shut down over the past 50 years. Many of them could be regarded as petroleum brownfields because they have the presence, or potential presence, of contamination. Owners of these former gasoline stations (many of which have been cleaned up) may be in need of a profitable use for the land. At the same time, there is a large push to increase the amount of alternative fuels used in vehicles in the United States because of their numerous environmental, economic, and geopolitical advantages. All of these fuels require refueling facilities that are convenient to vehicles, which tend to be the same sites as former gasoline stations. However, these former gasoline stations are not suitable for all fuels, and it is critical to identify what ones could be used for certain alternative fuels.

In 2008, the U.S. Environmental Protection Agency (EPA) launched the RE-Powering America's Land initiative to encourage the development of renewable energy on potentially contaminated land. As part of this effort, EPA's Office of Underground Storage Tanks (OUST) is collaborating with the U.S. Department of Energy's (DOE's) National Renewable Energy Laboratory (NREL) to evaluate the feasibility of siting alternative fuel stations at former gasoline station sites.

This report describes NREL's methodology for determining if a former gasoline station would be a good site to sell a given alternative fuel. It first does this at a regional level, where multiple regions and corridors that have favorable conditions for selling alternative fuels are identified. It then focuses on one particularly promising fuel/corridor combination-electric vehicles (EVs) on the Interstate 5 (I-5) corridor from Seattle, Washington, to Eugene, Oregon. The evaluation then focuses on specific sites within this corridor and presents a checklist for site owners to selfevaluate their potential to sell electricity to EVs. This checklist is brought to life through two case studies of real former gasoline stations on the I-5 corridor. Finally, this report offers practical guidelines on how a site owner gets the proper electric vehicle supply equipment (EVSE) installed, permitted, paid for, and operational. 


\section{Alternative Fuels Considered}

This assessment considers five alternative fuels to varying degrees. A thorough breakdown of these fuels, their compatible vehicles, preferred markets, relative strengths and weaknesses, and required infrastructure can be viewed at the AFDC. In this report, greater focus is given to fuels with larger need for new refueling infrastructure and with greater requirements for strategic deployment of infrastructure. Strategic deployment is generally required for fuels that have no ready substitute in the vehicle using them and fuels whose vehicles have more limited range. The fuels considered in this report are displayed in Table 1.

Table 1. Alternative Transportation Fuels, Vehicle Characteristics, and Deployment Strategy

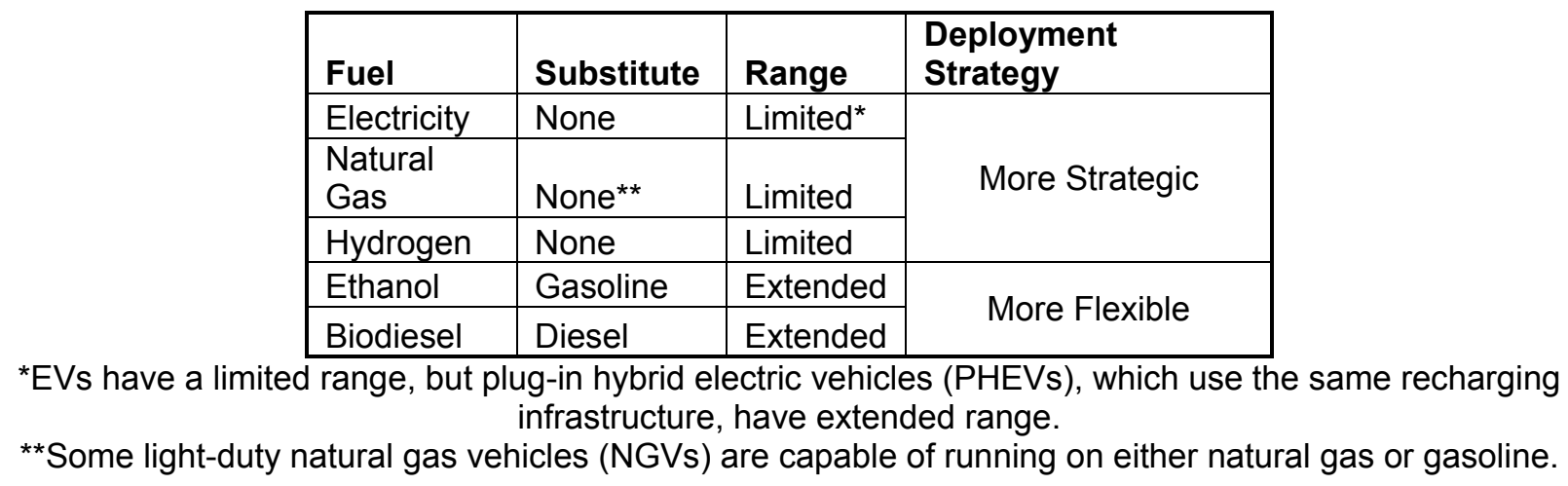

It is possible to combine refueling facilities for more than one fuel on the same property. Some fuels have synergies. For example, the most economical way of making hydrogen is to reform it from natural gas. Therefore, an on-site reformer and hydrogen station pairs well with a natural gas station. Another good pairing is ethanol and biodiesel because there are substantial cost savings if the equipment for both is installed at the same time (in the same hole and through the same dispensers) as opposed to separately. There are also limitations to what refueling stations can share the same property. Electrical charging stations will require a certain distance (not yet determined) from most other liquid and gaseous fuels in order to eliminate the threat of spark ignition. 


\section{Screening Criteria}

NREL has access to numerous geographic data sources that serve as criteria to screen locations where an alternative fuel would best be sold. These criteria are first applied to the entire nation to identify regions in need of refueling infrastructure and then applied to the local level to specify what locations would be best for retailing specific fuels. This section outlines these criteria in the order that they are prioritized and leaves discussion of how these screening criteria are prioritized and an assessment of available data for Section 4. This section shows maps of the criteria that apply to all fuels, while the fuel-specific maps are in Section 5.

\subsection{Land Revitalization Corridors}

Given the purpose of this project, the first criterion to determine what regions are suitable for alternative fuels is whether or not it has a land revitalization corridor. These are corridors where EPA, in conjunction with state and local partners, is helping to facilitate efforts to get former gasoline stations into reuse while protecting human health and the environment. These corridors are listed in Table 2 and mapped in Figure 1.

Table 2. Land Revitalization Corridors and Locations (Ordered East to West)

\begin{tabular}{|l|l|}
\hline Description & City or State \\
\hline Route 1, from CT to ME & CT, RI, MA, NH, ME \\
\hline Fulton Street between Broadway and Water Street & New York City \\
\hline Manor Street corridor of Cabbage Hill & Lancaster, PA \\
\hline Route 1 within College Park, MD, city limits & College Park, MD \\
\hline Money Point corridor & Chesapeake, VA \\
\hline Route 1 (I-95) north of Quantico to the state line & VA \\
\hline Highway 41 within Manatee and Sarasota counties & FL \\
\hline I-26 Corridor from Woodfin to Flat Rock, NC & NC \\
\hline Highway 285 beltline around Atlanta, GA & GA \\
\hline Highway 80 from Montgomery, AL, to Selma, AL & AL \\
\hline I-75/90 from Detroit to Cleveland & MI and OH \\
\hline $\begin{array}{l}\text { South Third and Fourth Streets, from Winkler Avenue and Industry Road to } \\
\text { Central Avenue }\end{array}$ & Louisville, KY \\
\hline Hancock county & IN \\
\hline Keystone Avenue interchange (with I-465 on the north side of Indianapolis) & Indianapolis, IN \\
\hline Milwaukee's 30th Street industrial corridor & Milwaukee, WI \\
\hline All of Route 66 in IL & IL \\
\hline Lincoln Highway through IA, NE, and KS & IA, NE, KS \\
\hline Phalen, Great Northern, and Rice Street & St. Paul, MN \\
\hline Kansas City (Troost \& Prospect corridors) & Kansas City, MO \\
\hline I-45 from Dallas to Houston & TX \\
\hline Route 66 within Sayre, OK & Sayre, OK \\
\hline Route 66 through all of TX & TX \\
\hline
\end{tabular}




\begin{tabular}{|l|l|}
\hline Colorado Historic Byways Initiative & CO \\
\hline Route 66 through AZ and CA & AZ and CA \\
\hline California's Highway 99 (or State Route 99) & CA \\
\hline I-5 in Clark County, WA & WA \\
\hline
\end{tabular}

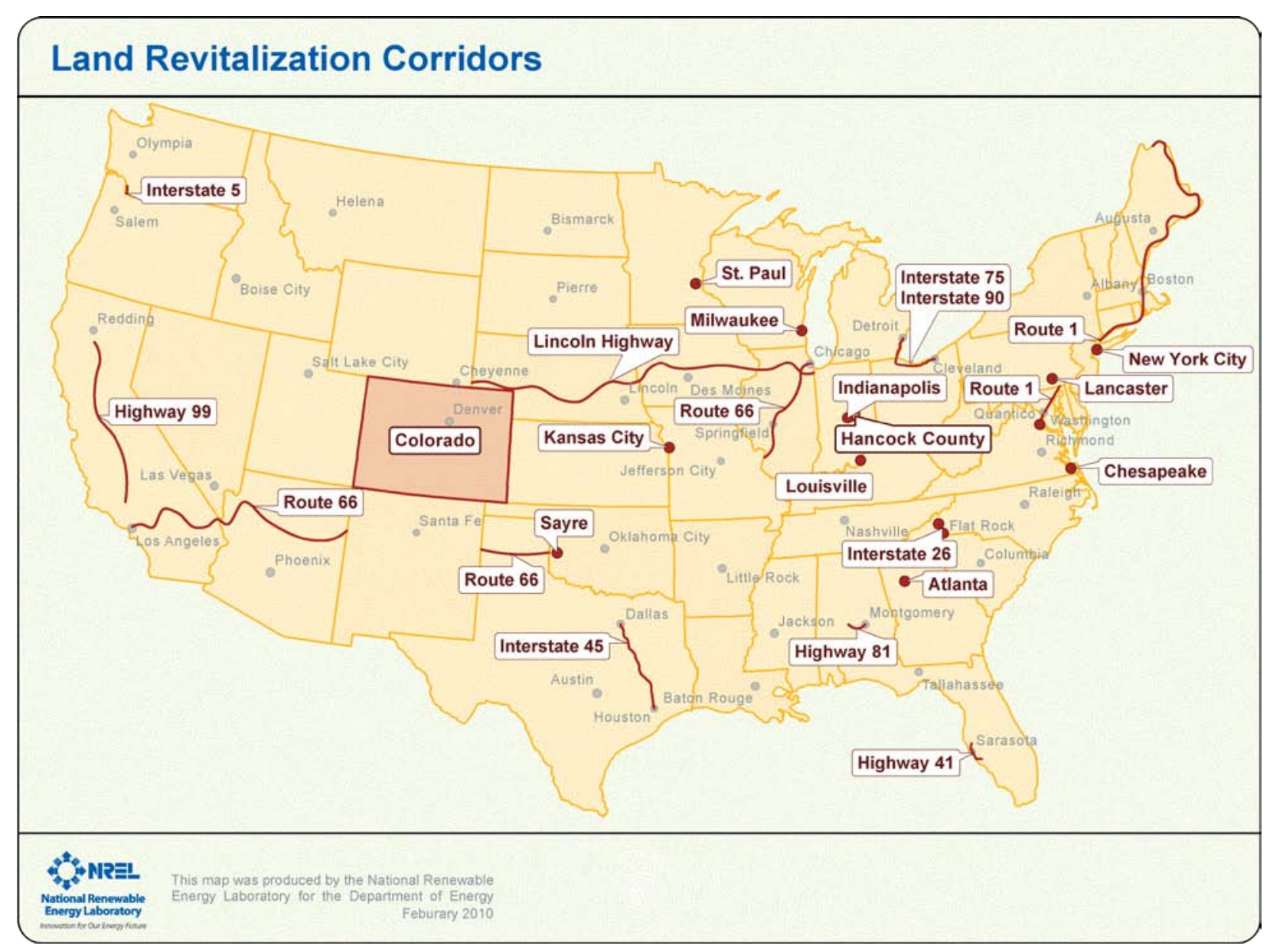

Figure 1. Map of land revitalization corridors

\subsection{Local Target Areas}

Some alternative fuels have extremely strong support at the local level. This support is represented by such factors as signing on to programs that promote specific fuels, devoting grants toward the fuel, and enacting legislation to promote a specific fuel. These factors are aggregated by the AFDC Incentives and Laws Web page, ${ }^{2}$ programs such as Project Get Ready, ${ }^{3}$ major grant funding, and other players depending on the fuel.

${ }^{2}$ U.S. Department of Energy. "Federal \& State Incentives \& Laws.” www.afdc.energy.gov/afdc/laws/. Accessed April 2011.

${ }^{3}$ Project Get Ready. www.projectgetready.org/. Accessed April 2011. 


\subsection{Existing Infrastructure}

Refueling infrastructure is a prime indicator of where a given fuel is currently being used. If refueling stations are operating, it is assumed that there are vehicles that can use the fuel and a population that is willing to use the fuel. NREL tracks the fueling stations selling alternative fuels and makes the data available at the AFDC Alternative Fueling Stations Web page. ${ }^{4}$ Maps for each fuel will be shown in Section 5.

\subsection{Gasoline Prices}

When other factors are equal, higher gasoline prices improve the economic case for using alternative fuels. Therefore, gasoline prices have been taken into consideration when deciding, for the purposes of this study, which regions of the nation to target with alternative fuels.

Figure 2 maps the average gasoline prices throughout the United States. In general, it is cheapest in the Southeast and gets more expensive as you move north or west. California has the most expensive gasoline, followed by New York, Connecticut, Washington, and Oregon.

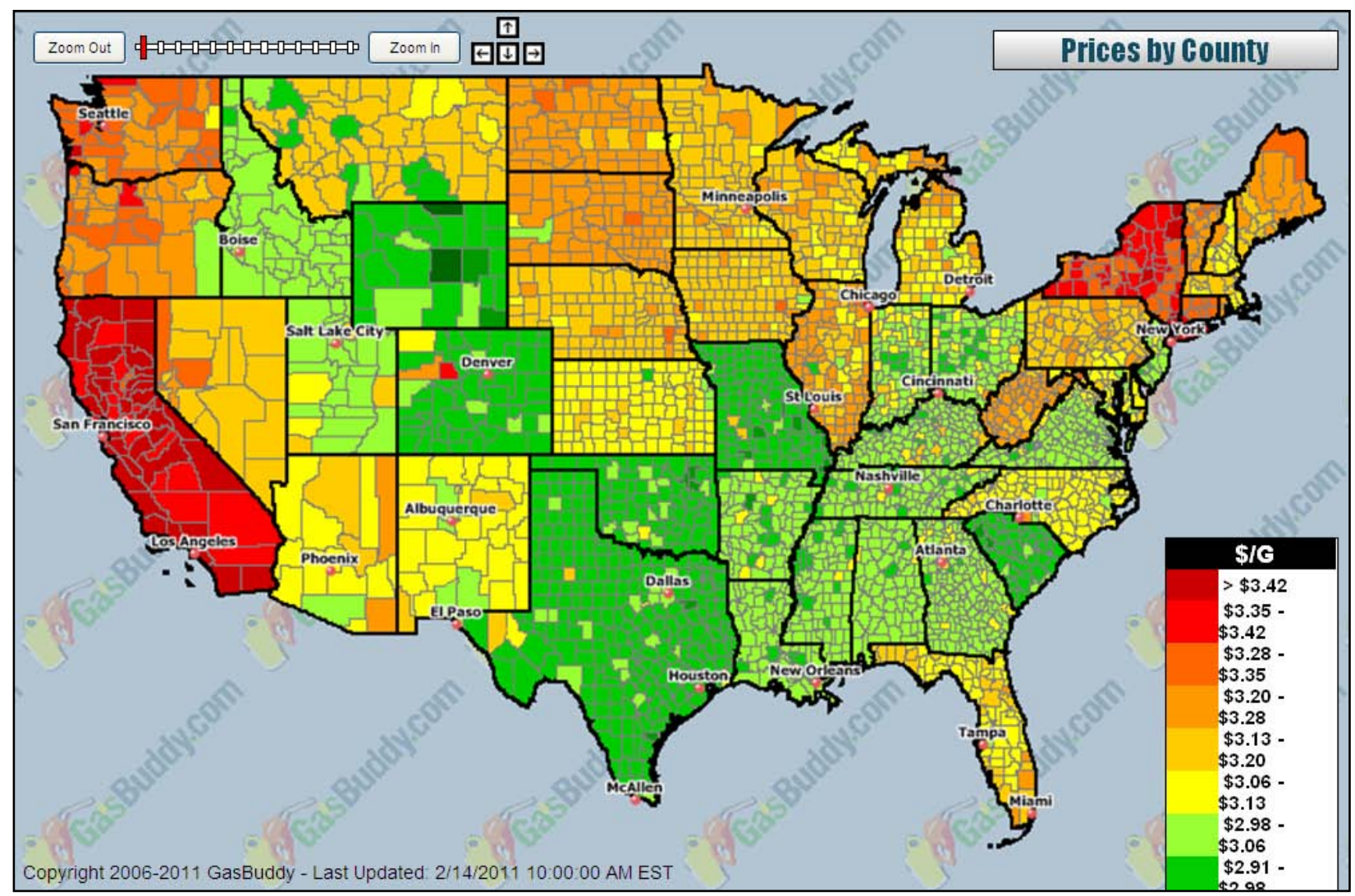

Figure 2. Map of snapshot gasoline prices averaged by county in the United States Source: USA National Gas Price Heat Map, Gasbuddy.com, 2/14/2011

\subsection{Vehicle Density}

The density of alternative fuel vehicles (AFVs) using a given fuel (in vehicles per square mile) is another good indicator for the potential use of that fuel. NREL calculates the density by dividing

\footnotetext{
${ }^{4}$ U.S. Department of Energy. “Alternative Fueling Stations.” www.afdc.energy.gov/afdc/fuels/stations.html. Accessed April 2011.
} 
the number of vehicles per zip code (purchased from R.L. Polk \& Co.) by the area of that zip code and has mapped it in Figures 4 and 9. Density is preferred over the direct number because it helps take into account the fact that people have a limited distance that they are willing to drive to refuel. Therefore, density provides a better representation of the number of AFVs that could conveniently refuel at a given location rather than the number that could possibly refuel there if they were willing to drive across an entire zip code.

\subsection{State Incentives}

State incentives toward a given fuel make that fuel more attractive to use. These incentives range from tax credits for installing refueling infrastructure to allowing AFVs to drive in the high-occupancy vehicle (HOV) lanes. State incentives are tracked by the Incentives and Laws Web page on the AFDC and are mapped in Figures 3, 6, 7, 8, and 10.

\subsection{Environmental Advantage}

Environmental benefit is one of the most commonly cited reasons for using alternative fuels. For some alternative fuels (namely electricity), this benefit is dependent on location. The environmental benefits of most other fuels are relatively consistent across locations and therefore not relevant when assessing where to locate the fueling infrastructure of these fuels.

\footnotetext{
${ }^{5}$ U.S. Department of Energy. "Federal \& State Incentives \& Laws.” www.afdc.energy.gov/afdc/laws/. Accessed April 2011.
} 


\section{Prioritization and Availability of Screening Criteria}

Not all of the screening criteria were given equal weight; nor do they all have the same level of data availability. Table 3 lists the criteria, as prioritized from left to right, along with the availability of the data.

Table 3. Screening Criteria for Location Choice, Weighting, and Data Availability

\begin{tabular}{|c|c|c|c|c|c|c|c|}
\hline$\stackrel{\overline{\mathbf{d}}}{\vec{\nu}}$ & 兽 & 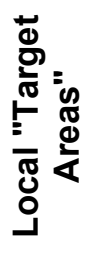 & 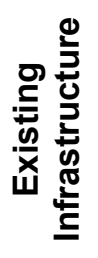 & 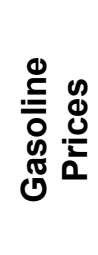 & 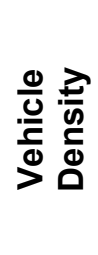 & 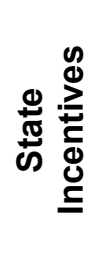 & 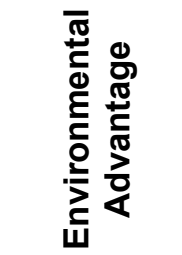 \\
\hline Criteria Weight & \multicolumn{7}{|c|}{ Heavy <--1 } \\
\hline Electricity & $\mathrm{X}$ & $\mathrm{X}$ & $\mathrm{x}$ & $\mathrm{x}$ & $\mathrm{x}$ & $\mathrm{x}$ & $\mathrm{x}$ \\
\hline Natural Gas & $\mathrm{X}$ & - & $\mathrm{X}$ & $\mathrm{x}$ & - & $\mathrm{x}$ & Consistent \\
\hline Hydrogen & $\mathrm{X}$ & $\mathrm{X}$ & $\mathrm{X}$ & $x$ & - & $\mathrm{X}$ & Consistent \\
\hline Ethanol & $\mathrm{X}$ & - & $\mathrm{X}$ & $\mathrm{X}$ & $x$ & $X$ & Consistent \\
\hline Biodiesel & $X$ & - & $X$ & $X$ & - & $X$ & Consistent \\
\hline
\end{tabular}

$X$ denotes that NREL has applicable data to map, and it is suitable to inform decisions.

- denotes that no applicable data is available.

"Consistent" means that the environmental advantage does not depend on location.

Land revitalization corridor is the top priority because the purpose of this project is to point out former gasoline station sites that would be appropriate to revitalize. This project builds upon work done by EPA to determine the corridors where revitalization is needed. This corridor data is relevant to all fuels.

Local "target areas" include a series of factors that reflect the fuel's popularity in the local population as represented through their elected government. These factors are given much weight because they represent commitments made and funds allocated towards the adoption of an alternative fuel in a given area. As such, these factors are weighted more heavily than existing infrastructure because they represent conditions that are current or even forthcoming while the existing infrastructure represents current and sometimes past conditions. Only two of the fuels (electricity and hydrogen) have reliable data for target areas. This criterion is not considered for the other three fuels.

Existing infrastructure is weighted more heavily than gasoline prices because it is assumed to take into account a variety of factors, including gasoline prices, that make retailing a fuel favorable within a given region. This data is available and relevant to all fuels.

Gasoline prices are weighted more heavily than vehicle density for two reasons. One is that the most popular AFVs are flex-fueled vehicles (FFVs), which usually run on gasoline if the price of gasoline is cheaper. The other reason is that the other vehicles that are mapped, HEVs, are assumed to be closely tied to higher gasoline prices. This assumption stems from temporal 
trends linking HEV sales to gasoline prices. ${ }^{6}$ Gasoline prices are available and relevant to all fuels.

Vehicle density is prioritized over state incentives because the quantity of state incentives is not tied very closely to the efficacy of those incentives. NREL has vehicle density data for FFVs and HEVs (which is used as a proxy for electric vehicles).

State incentives are the lowest priority criteria in cases where the environmental advantage is highly valued. NREL has state incentive data for all of the fuels.

Environmental advantage could be at the bottom of the prioritization list or rise much higher depending on two factors: (1) The motivation of the project partners. Do they want to support alternative fuels for environmental reasons or other reasons? (2) What fuel are they considering? The environmental advantage of most fuels is the same regardless of where it is used, which renders this factor irrelevant for those fuels. The exception to this factor is electricity, whose effect on climate change varies widely according to region. This will be discussed in greater depth in the next section.

\footnotetext{
${ }^{6}$ Benton, J. "Hybrid Sales and Prices Climb in Lockstep with Gas Prices." ConsumerAffairs.com, May 16, 2008.
} 


\section{Fuel-Specific Location Assessment}

In order to identify the best regions to convert former gasoline stations to sell alternative fuels, the screening criteria were applied to each alternative fuel individually.

\subsection{Electricity}

Electricity and EVs currently benefit from numerous local initiatives pushing to encourage infrastructure expansion. This assessment for EV's takes four types of local initiatives into account. These local initiatives are detailed next and listed by location in Table 4.

1. ARRA EV Grant Recipients. \$145 million was designated to EV deployment projects in the American Recovery and Reinvestment Act of 2009 (ARRA) (www.recovery.gov). Direct recipients and sub-awards are located in 19 different locations.

2. Clean Cities Grant Recipients. \$69 million of ARRA funding was sent through DOE's Clean Cities program to support EV deployment in five locations (www.energy.gov/recovery/cleancities.htm).

3. Project Get Ready. The Rocky Mountain Institute is running Project Get Ready to help cities prepare for EV-based transportation. Eight U.S. cities have signed up with Project Get Ready and have developed plans to expand EV infrastructure (http://projectgetready.com/category/city).

4. City-Based Incentives. Incentives that promote EV purchases or the installation of charging infrastructure are tracked at www.afdc.energy.gov/afdc/laws/. In addition to the multiple state incentives (to be discussed in Section 5), six municipal governments issued their own incentives.

Table 4. Local Initiatives to Install EV Charging Infrastructure

\begin{tabular}{|l|l|l|}
\hline City & State & Local Initiative \\
\hline Phoenix & AZ & ARRA EV Grant Recipient \\
\hline Tucson & AZ & ARRA EV Grant Recipient \\
\hline Los Angeles & CA & City-Based Incentive \\
\hline Oakland & CA & City-Based Incentive \\
\hline Sacramento & CA & City-Based Incentive \\
\hline San Diego & & ARRA EV Grant Recipient + City-Based \\
\hline San Francisco Bay Area & CA & Incentive \\
\hline San Jose & CA & City-Based Incentive \\
\hline West Covina & CA & City-Based Incentive \\
\hline Greater Denver & CA & ARRA EV Grant Recipient \\
\hline New Haven & CO & Project Get Ready \\
\hline Orlando & CT & Clean Cities Grant Recipient \\
\hline Surfside & FL & Project Get Ready \\
\hline Chicago & FL & ARRA EV Grant Recipient \\
\hline Indianapolis region & IL & Clean Cities Grant Recipient \\
\hline Annapolis & IN & Project Get Ready \\
\hline Ramsey County & MD & ARRA EV Grant Recipient \\
\hline Kansas City region & MN & ARRA EV Grant Recipient \\
\hline & & Clean Cities Grant Recipient + Project Get \\
\hline
\end{tabular}




\begin{tabular}{|l|l|l|}
\hline $\begin{array}{l}\text { Seven-county region around } \\
\text { Raleigh }\end{array}$ & NC & $\begin{array}{l}\text { Clean Cities Grant Recipient + Project Get } \\
\text { Ready }\end{array}$ \\
\hline New York City & NY & ARRA EV Grant Recipient \\
\hline Corvallis & OR & ARRA EV Grant Recipient \\
\hline Eugene & OR & ARRA EV Grant Recipient \\
\hline Portland & & ARRA EV Grant Recipient + Project Get \\
\hline Salem & OR & Ready \\
\hline Statewide & OR & ARRA EV Grant Recipient \\
\hline Chattanooga & RI & Project Get Ready \\
\hline Knoxville & TN & ARRA EV Grant Recipient \\
\hline Nashville & TN & ARRA EV Grant Recipient \\
\hline Dallas-Fort Worth & TN & ARRA EV Grant Recipient \\
\hline Houston & TX & Clean Cities Grant Recipient \\
\hline San Antonio & TX & Project Get Ready \\
\hline Auburn & TX & ARRA EV Grant Recipient \\
\hline Seattle & WA & ARRA EV Grant Recipient \\
\hline I-5 through Washington & WA & ARRA EV Grant Recipient \\
\hline & WA & ARRA EV Grant Recipient \\
\hline
\end{tabular}

Figure 3 shows local initiatives, current EV charging infrastructure, and state incentives encouraging EVs and charging infrastructure. The charging infrastructure includes all three levels of charging (to be explained in Section 6.1). State incentives can range from passes for EVs to drive in HOV lanes up to a Colorado tax credit that covers $85 \%$ of the additional cost of an EV. The state incentives are listed on the AFDC Incentives and Laws Web page. ${ }^{7}$ The black circles on Figure 3 highlight the areas where these four factors combine to make the market particularly receptive to new EV infrastructure projects.

${ }^{7}$ U.S. Department of Energy. "Federal \& State Incentives \& Laws.” www.afdc.energy.gov/afdc/laws/. Accessed April 2011. 


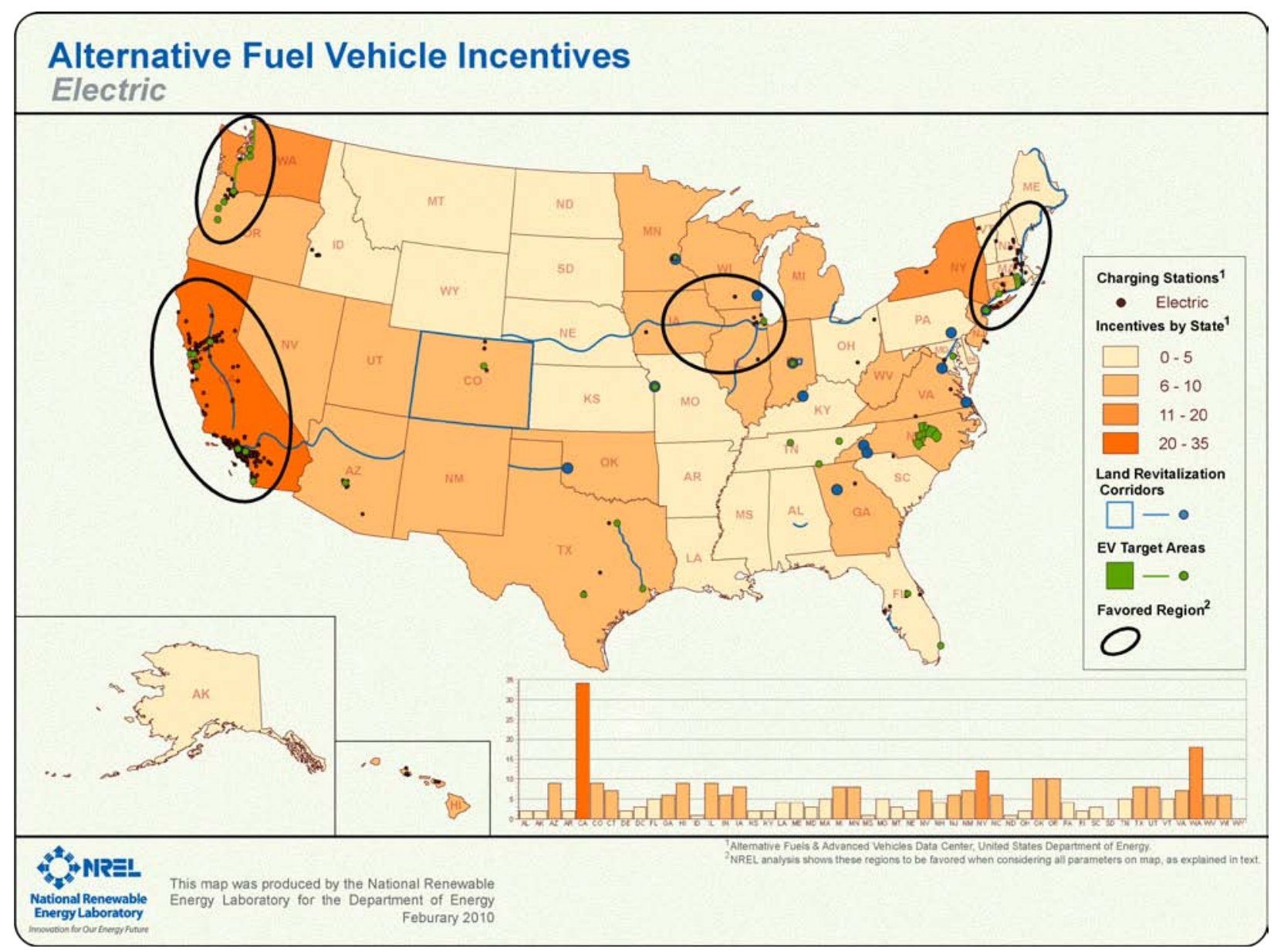

Figure 3. Land revitalization corridors, EV infrastructure, and the local initiatives and state incentives supporting it

The next logical question is: Where do the people who will purchase EVs live? To answer this question, it is assumed that the populations that have purchased the most HEVs will also be the populations to purchase EVs. This logic is based on the idea that people who purchase cutting edge, clean vehicles will continue to stay on the cutting edge as technology progresses. Figure 4 shows a map of the HEV densities, charging stations, local focus areas, and land revitalization corridors. The regions showing high potential are circled in black. These areas are the same as in Figure 3, with the addition of three new regions-Highway 1 from the greater Washington, D.C., area to Portland, Maine; the Atlanta-Chattanooga-Nashville-Knoxville area; and the DallasHouston corridor. 


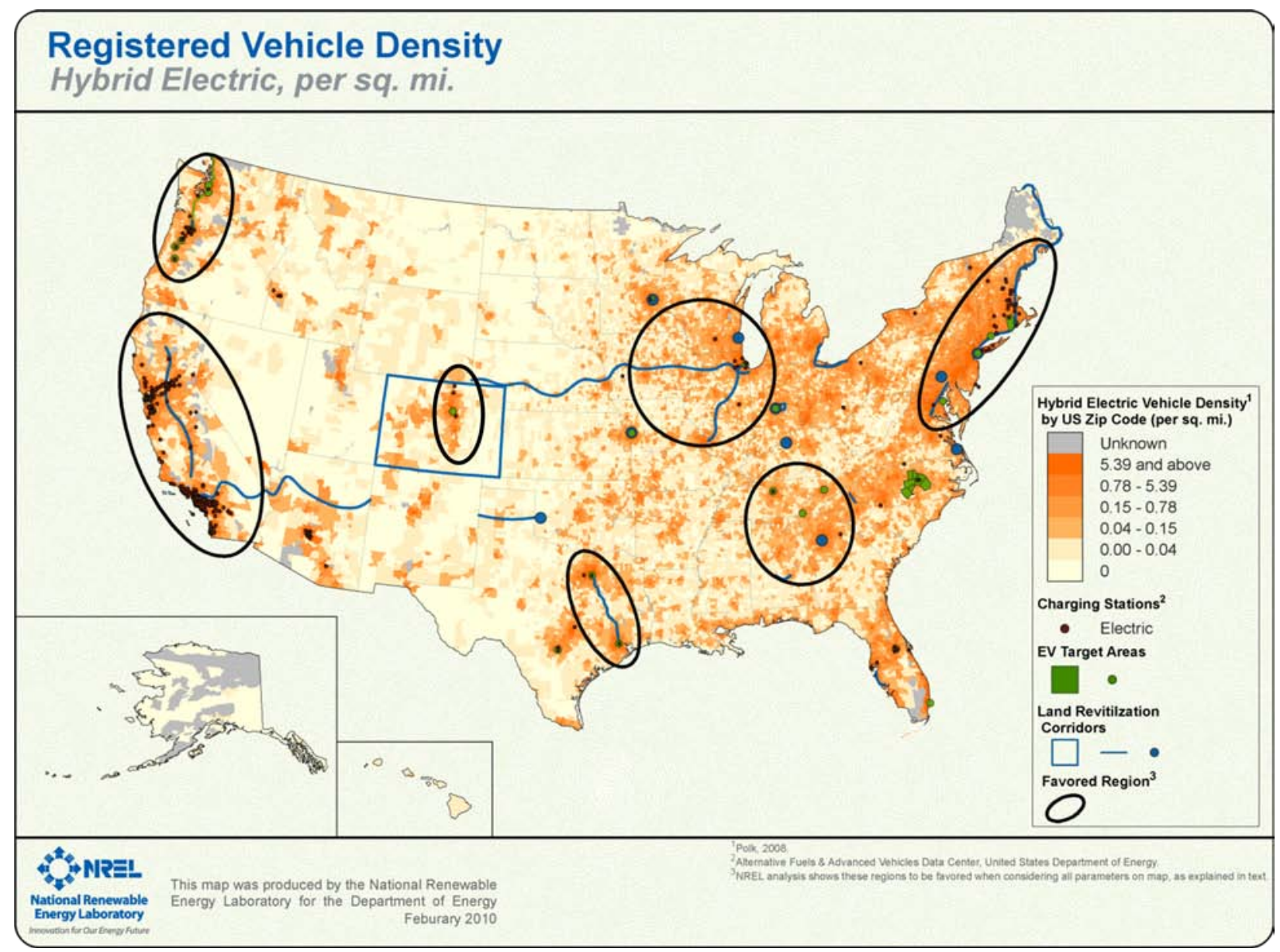

Figure 4. Land revitalization corridors, EV infrastructure, and HEV density by county

The environmental benefits of EVs depend on where the EV is located. This is because the greenhouse gas (GHG) intensity of electricity varies greatly depending on the fuel source and, therefore, the location. Figure 5 shows this GHG intensity and, therefore, the most environmentally beneficial places to promote EV and charging infrastructure. The data source is EPA's Emissions \& Generation Resource Integrated Database (eGRID), ${ }^{8}$ which is then interpolated between power plants so that a location that is closer to a high-emitting (usually inefficient or coal-burning) power plant shows up as a having electricity with a higher GHG intensity. The black circles show that the same areas that looked favorable for EVs on the HEV map also look favorable on the GHG intensity map, with the exception of the Dallas-Houston corridor, the greater Denver area, and the greater Chicago area. The Seattle-Eugene corridor looks particularly favorable, with its abundance of renewable electricity.

\footnotetext{
${ }^{8}$ U.S. Environmental Protection Agency. "eGRID.” Version 1. www.epa.gov/cleanenergy/energyresources/egrid/index.html. Accessed April 2011.
} 


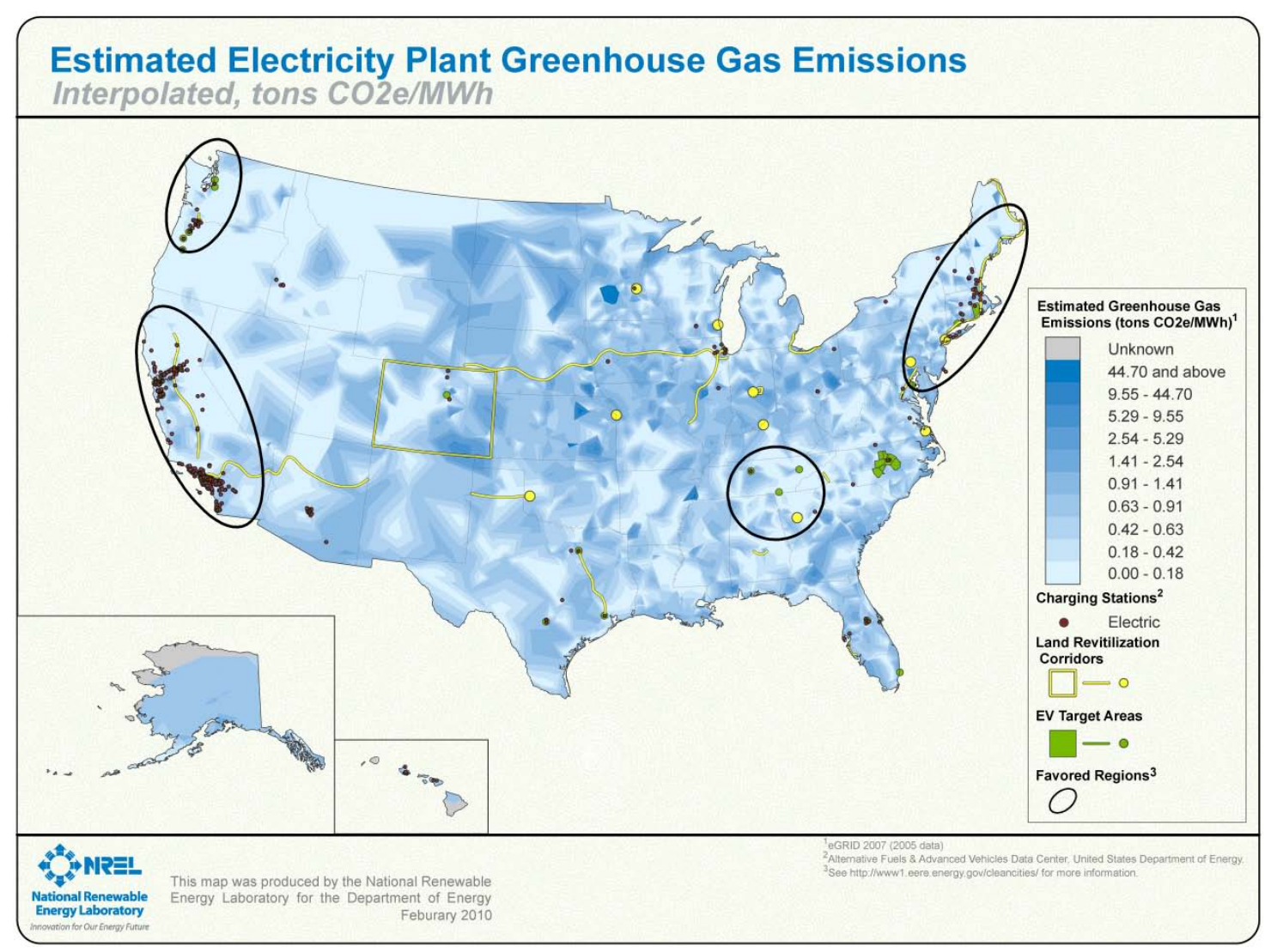

Figure 5. GHG intensity, land revitalization corridors, and EV infrastructure

Table 5 lists the regions that are the best candidates for the installation of electric charging stations when all factors are taken into account. It then ranks them qualitatively based on if they are a favorable location for EV infrastructure as previously discussed. The Seattle-Eugene and San Francisco-Los Angeles corridors are the top priority because they both are favorable in all seven factors. The regions listed as second priority are all favorable for six of the seven criteria, with gasoline cost being the unfulfilled criteria for all except Route 66 out of Los Angeles. The third-ranked locations both look unfavorable for two criteria, the fourth-ranked have three unfavorable criteria, and the fifth-ranked have six unfavorable criteria.

Table 5. Prioritization of Regions for EV Infrastructure According to Seven Major Criteria

\begin{tabular}{|c|c|c|c|c|c|c|c|c|c|}
\hline 른 & 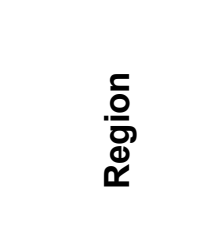 & $\begin{array}{l}\text { ते } \\
\frac{3}{E} \\
\text { o. } \\
\text { 至 }\end{array}$ & 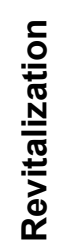 & 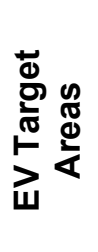 & 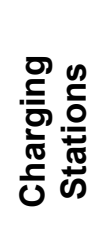 & 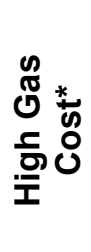 & $\sum_{\text {岂 }}^{\infty}$ & 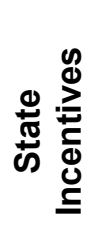 & 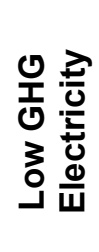 \\
\hline \multirow[b]{2}{*}{1} & $\begin{array}{l}\text { Seattle- } \\
\text { Eugene }\end{array}$ & Hwy 95 & $Y$ & $Y$ & $\mathrm{Y}$ & $Y$ & $Y$ & $Y$ & $Y$ \\
\hline & $\begin{array}{l}\text { San } \\
\text { Francisco- } \\
\text { Los Angeles }\end{array}$ & Hwy 99 & $Y$ & $Y$ & $\mathrm{Y}$ & $Y$ & $Y$ & $Y$ & $Y$ \\
\hline
\end{tabular}




\begin{tabular}{|c|c|c|c|c|c|c|c|c|c|}
\hline \multirow{3}{*}{2} & $\begin{array}{l}\text { New York } \\
\text { City- } \\
\text { Portland, ME }\end{array}$ & Route 1 & $Y$ & Y & $Y$ & $\mathrm{~N}$ & $Y$ & $Y$ & $Y$ \\
\hline & $\begin{array}{l}\text { Greater } \\
\text { Washington, } \\
\text { D.C. }\end{array}$ & Route 1 & $Y$ & Y & Y & $\mathrm{N}$ & Y & $Y$ & $Y$ \\
\hline & $\begin{array}{l}\text { Los Angeles } \\
\text { East }\end{array}$ & Route 66 & $Y$ & Y & Y & $Y$ & Y & $\mathrm{Y}$ & $\mathrm{N}$ \\
\hline \multirow{2}{*}{3} & $\begin{array}{l}\text { Chicago- } \\
\text { Milwaukee }\end{array}$ & $\begin{array}{l}\text { Lincoln and } \\
\text { Route } 66\end{array}$ & $Y$ & Y & Y & $\mathrm{N}$ & Y & $Y$ & $\mathrm{~N}$ \\
\hline & $\begin{array}{l}\text { Atlanta- } \\
\text { Nashville }\end{array}$ & I-75/I-24 & $Y$ & $Y$ & $\mathrm{~N}$ & $\mathrm{~N}$ & $Y$ & $Y$ & $Y$ \\
\hline \multirow[b]{2}{*}{4} & Denver, CO & I-25/Hwy 36 & $\mathrm{Y}$ & $Y$ & $\mathrm{~N}$ & $\mathrm{~N}$ & $Y$ & $\mathrm{Y}$ & $\mathrm{N}$ \\
\hline & $\begin{array}{l}\text { Dallas- } \\
\text { Houston }\end{array}$ & $\mathrm{I}-45$ & $\mathrm{~N}$ & $Y$ & $Y$ & $\mathrm{~N}$ & Y & $Y$ & $\mathrm{~N}$ \\
\hline 5 & $\begin{array}{l}\text { Detroit- } \\
\text { Cleveland }\end{array}$ & I-90/275 & $\mathrm{N}$ & $\mathrm{N}$ & $\mathrm{N}$ & $\mathrm{N}$ & Y & $\mathrm{N}$ & $\mathrm{N}$ \\
\hline
\end{tabular}

${ }^{*}$ As in Figure 2, high gasoline cost means over $\$ 3.28$ over a majority of the corridor.

\subsection{Natural Gas}

Natural gas vehicles (NGVs), like EVs, have a limited range. However, their deployment strategy is fundamentally different than EVs because most NGVs are heavy-duty vehicles. As such, NGVs tend to be used in fleets of transit buses, refuse trucks, school buses, and delivery trucks. These vehicles all have circular routes that lend themselves well to refueling at the same station every time. However, greater route flexibility and range is added if two or more stations are established within driving range of one another. This range enhancement can be optimized by placing stations along a corridor. Having other stations nearby also reduces operating costs because multiple stations can hire a single contractor to be on call for station breakdowns and emergencies.

Figure 6 illustrates where some of these synergies between stations might best be achieved on former gasoline station sites. Natural gas corridors are already being developed on I-5 in Washington and Oregon, I-99 and Route 66 in California, and Route 1 from Virginia to Massachusetts. There is a strong base of stations in the Chicago-Milwaukee area, which presents the opportunity for stations to expand west and south along designated land revitalization corridors. This map does not include "hot spots" comparable to EV hot spots because all but two incentives listed in the AFDC are state-based instead of local, and the grant programs supporting natural gas infrastructure are spread out. The map does not include NGV density because that data is not currently available.

When the limited data for natural gas is taken into account, the four regions circled in purple on Figure 6 are the most favorable regions in the nation to install natural gas refueling infrastructure. These four regions also have relatively high gas prices - in this comparison, high gas prices means over $\$ 3.20$, as shown in Figure 2 . 


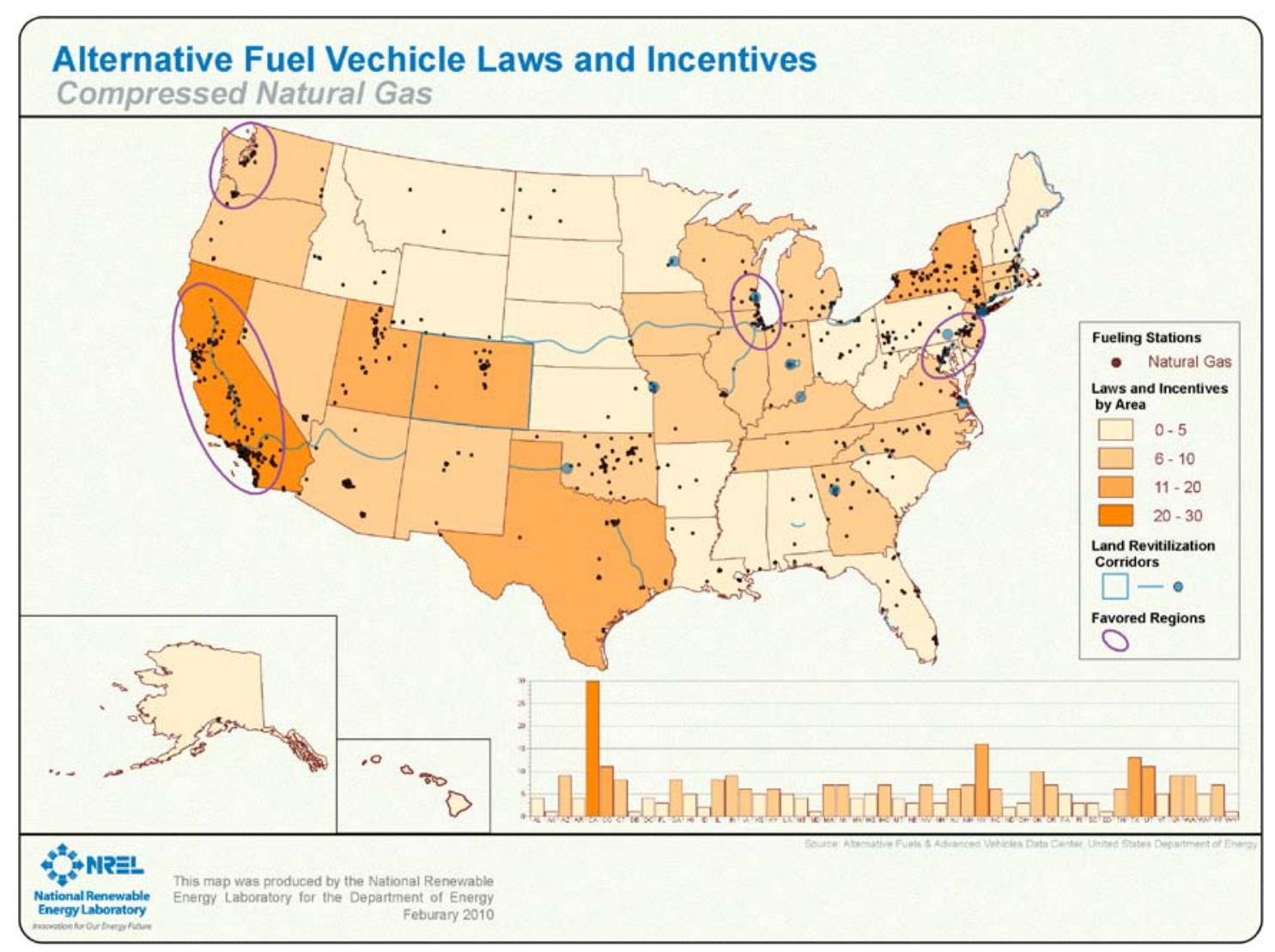

Figure 6. Natural gas stations, land revitalization corridors, and pro-natural-gas incentives

\subsection{Hydrogen}

Hydrogen requires the most strategic station placement of all. This is largely because there are so few existing stations, while the targeted population is light-duty vehicles instead of fleets with circular routes. Furthermore, hydrogen stations and vehicles require specialists to maintain them; these specialists are rare. Therefore, most hydrogen stations have been established as part of the California Fuel Cell Partnership in collaboration with DOE's Technology Validation Program. This partnership has established the Los Angeles and San Francisco areas as hubs from which to grow, so those two cities can be considered the "hot spots" for hydrogen. As shown in Figure 7, these two cities are the only promising places to add hydrogen stations when you take into account all of the available screening criteria (including gasoline prices). 


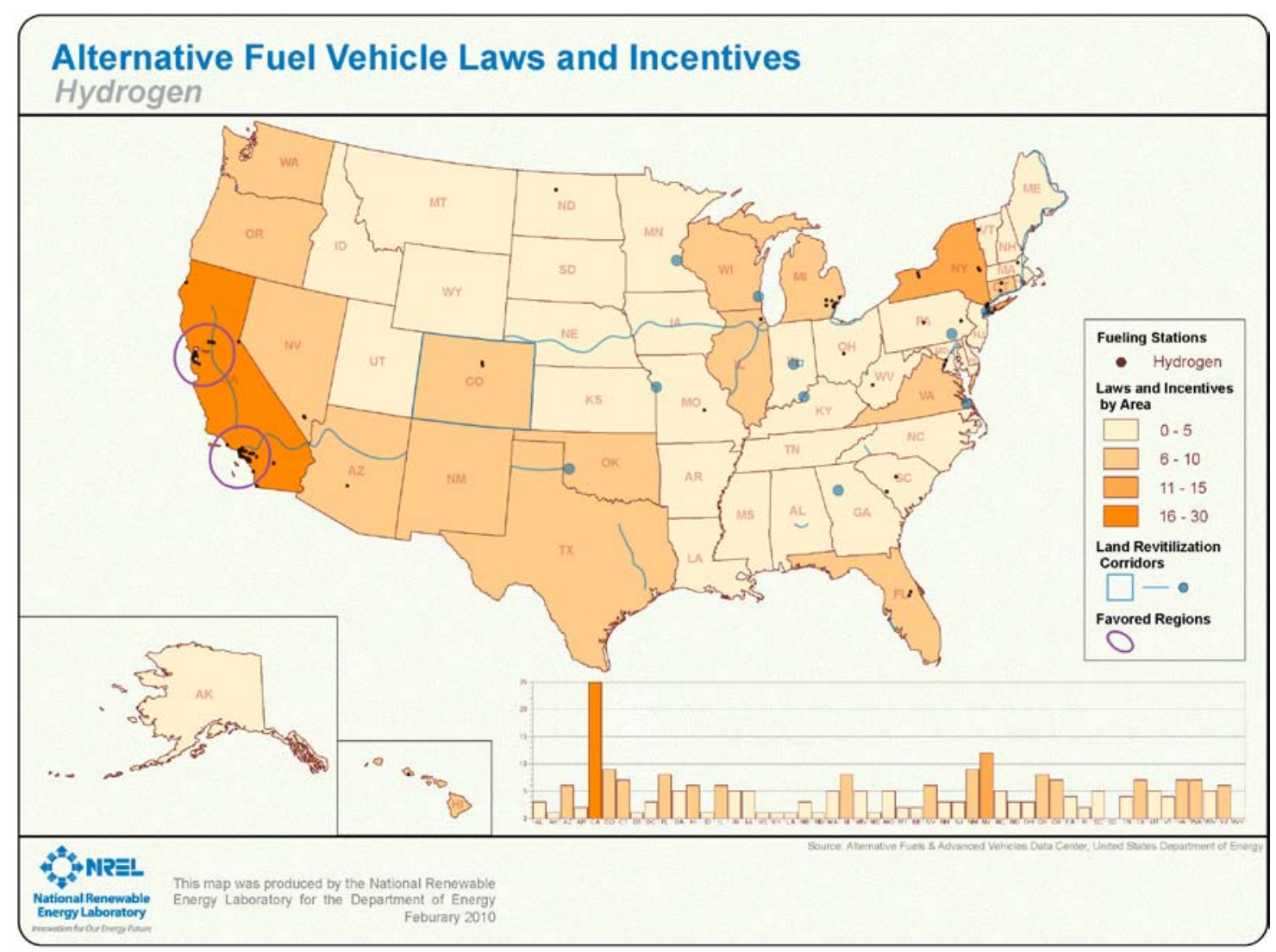

Figure 7. Hydrogen stations, land revitalization corridors, and pro-hydrogen incentives

\subsection{Ethanol}

Despite having the most developed refueling infrastructure of any of the alternative fuels and the FFV being one of the "more flexible" fuels, there is a great need for additional $85 \%$ ethanol (E85) refueling stations in America. This is because, at 8.35 million vehicles, ${ }^{9}$ the E85-capable FFVs are the most numerous AFVs, and there is more ethanol produced in this country than any other alternative fuel. Furthermore, the Renewable Fuel Standard II $^{10}$ requires 36 billion gallons of alternative fuel to be used by 2022, and ethanol (cellulosic and corn-based) is legislated to supply 31 million gallons of this.

When considering potential sites for E85 stations, it is of utmost importance to keep in mind where current stations are. There are four reasons for this. First, ethanol has no "hot spots" to take into account since it is promoted widely throughout the Midwest and beyond. Second, it is best to site new stations in regions where there are other stations because the other stations raise the customers' awareness for the fuel. Many FFV owners do not even know that they can use E85, but current E85 stations tend to participate in public awareness campaigns and advertisements. Third, a new station should not be located so close to an existing station that it competes with it for business. Finally, station operators should be interested in creating corridors

\footnotetext{
${ }^{9}$ U.S. Department of Energy. "Data, Analysis, \& Trends.” www.afdc.energy.gov/afdc/data/vehicles.html. Accessed April 2011.

${ }^{10}$ U.S. Environmental Protection Agency. "Renewable Fuels: Regulations \& Standards." www.epa.gov/oms/fuels/renewablefuels/regulations.htm. Accessed April 2011.
} 
of E85 stations and filling in gaps between stations that are located far apart. E85 stations are likely to do well when they are within the refueling range of a large number of FFVs driving on a roadway that are used to using E85.

Figure 8 serves as a useful tool for spotting promising locations for new E85 stations. All circled areas contain revitalization corridors within states that have six or more E85 incentives. The area around Chicago, Illinois, is circled as a good location because the concentration of E85 stations is already relatively high there. Therefore, the awareness of E85 by FFV owners and the E85 purchases per FFV should be relatively high there. This is affirmed by the fact that the Chicago Clean Cities Coalition ranks in the $85^{\text {th }}$ percentile (among 86 coalitions) for its per-FFV E85 use. ${ }^{11}$ The I-5 corridor through Oregon and Washington and the I-35 corridor in Texas (also circled) are favorable locations to add stations to relatively established corridors. Two areas are also circled (I-99 and Route 66 in California and Sayre, Oklahoma) that would be favorable opportunities to split gaps between groups of stations.

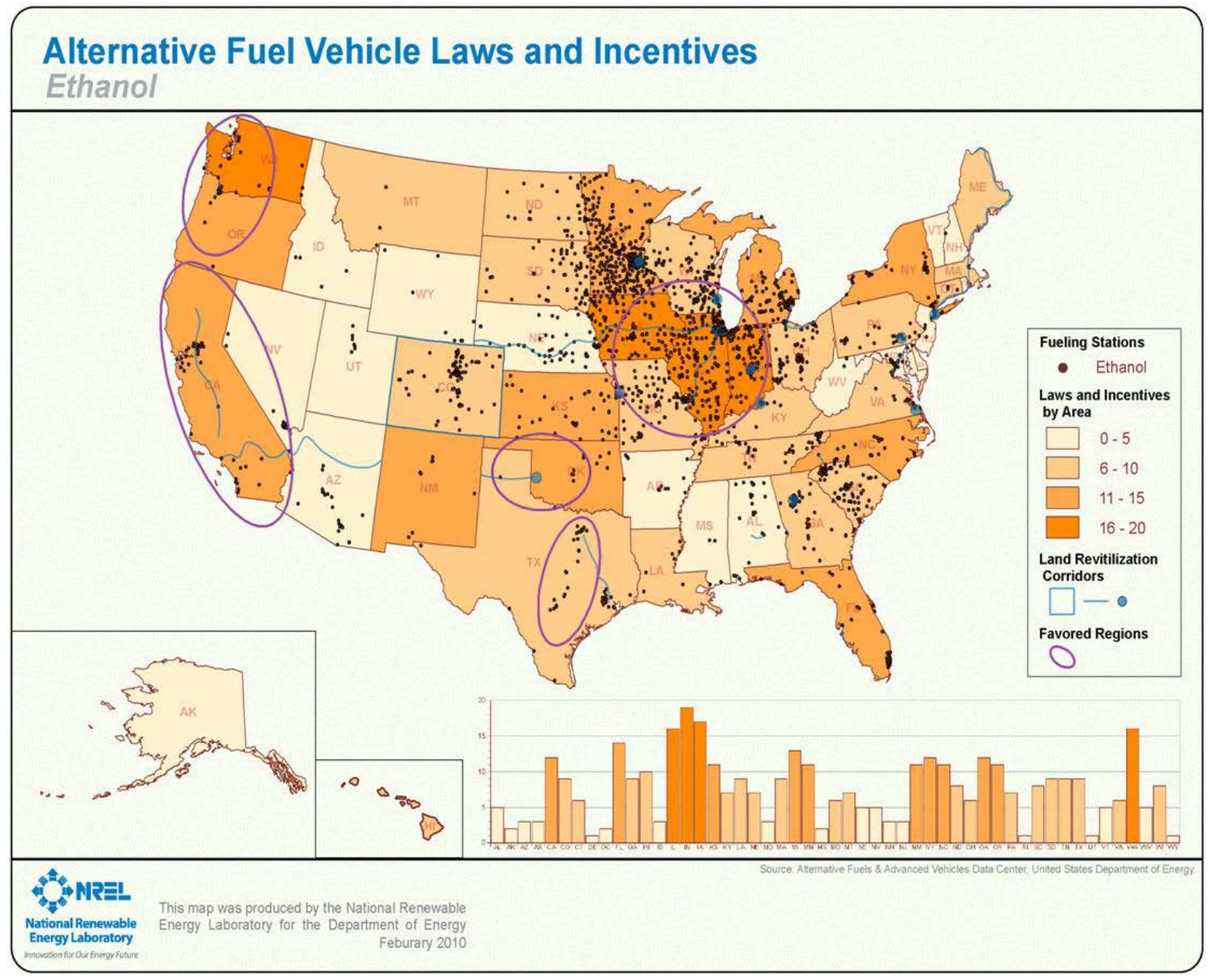

Figure 8. E85 stations, land revitalization corridors, and state ethanol incentives

\footnotetext{
${ }^{11}$ NREL calculations based on 2009 Clean Cities Annual Report data. www.afdc.energy.gov/afdc/data/cleancities.html. Accessed April 2011.
} 
The next criterion to be assessed is the density of FFVs, which is mapped in Figure 9. It confirms that four of the previous five areas are favorable locations to add E85 stations. The area that is not confirmed is Sayre, Oklahoma, because its FFV density is too low. The map also highlights two more regions-Route 1 from Washington, D.C., up through Boston and Highway 41 in Florida.

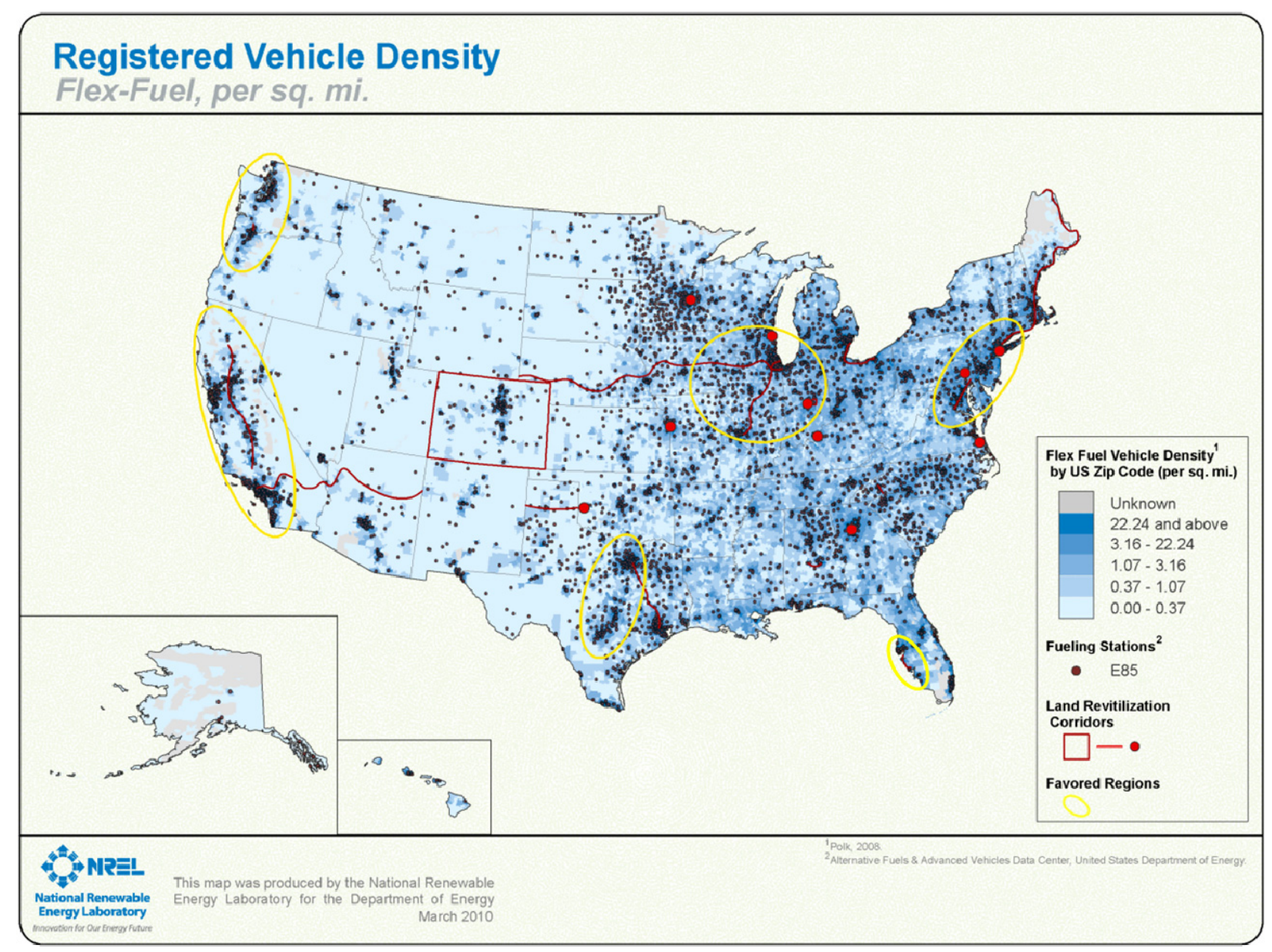

Figure 9. FFV density, E85 stations, and land revitalization corridors

Table 6 enables us to simplify and directly compare all of the screening criteria available for ethanol by region (as reported in Figures 2, 8, and 9). It highlights the four best regions to install E85 infrastructure, and three other regions that are less ideal. 
Table 6. Multi-Criteria Prioritization of Potential Ethanol Regions

\begin{tabular}{|c|c|c|c|c|c|c|}
\hline Region & Priority & $\begin{array}{c}\text { Land } \\
\text { Revitalization } \\
\text { Corridor }\end{array}$ & $\begin{array}{c}\text { Existing } \\
\text { Infrastructure }\end{array}$ & $\begin{array}{l}\text { Gasoline } \\
\text { Prices* }\end{array}$ & $\begin{array}{l}\text { Vehicle } \\
\text { Density }\end{array}$ & $\begin{array}{c}\text { State } \\
\text { Incentives }\end{array}$ \\
\hline Chicago-Milwaukee & \multirow{4}{*}{1} & $x$ & $X$ & $X$ & $x$ & $x$ \\
\hline Hwy 41 in Florida & & $x$ & $x$ & $x$ & $x$ & $x$ \\
\hline Seattle-Salem & & $x$ & $x$ & $x$ & $x$ & $x$ \\
\hline $\begin{array}{l}\text { San Francisco-Los } \\
\text { Angeles }\end{array}$ & & $X$ & $X$ & $x$ & $X$ & $X$ \\
\hline Sayre, Oklahoma & 2 & $x$ & - & - & & $\mathrm{X}$ \\
\hline $\begin{array}{l}\text { Washington, D.C.- } \\
\text { Boston }\end{array}$ & 3 & $x$ & - & - & $x$ & - \\
\hline San Antonio-Dallas & 4 & - & $\mathrm{X}$ & - & $x$ & - \\
\hline
\end{tabular}

${ }^{*} \mathrm{X}$ denotes gasoline prices greater than $\$ 3.13 /$ gallon, as shown in Figure 2.

${ }^{* *} \mathrm{X}$ denotes more than 10 incentives.

\subsection{Biodiesel}

Biodiesel can be used in regular diesel vehicles (with no alterations) in blends up to $20 \%$. Since special vehicles are not required to use it, locating biodiesel stations is even more flexible than ethanol stations. However, many of the same strategies that apply to ethanol also apply to biodiesel. The strategies of building in the vicinity of other stations to capitalize on consumer awareness and to bridge gaps between stations to make corridors for those desiring to use the fuel lead to the favored regions in Figure 10. After reviewing gasoline prices, the best locations are the I-5 corridor in Washington-Oregon and the two corridors in California. The Chicago area and Route 1 from Virginia to New York are also favorable but slightly less desirable because their cold climates can cause gelling issues in biodiesel in the winter. 


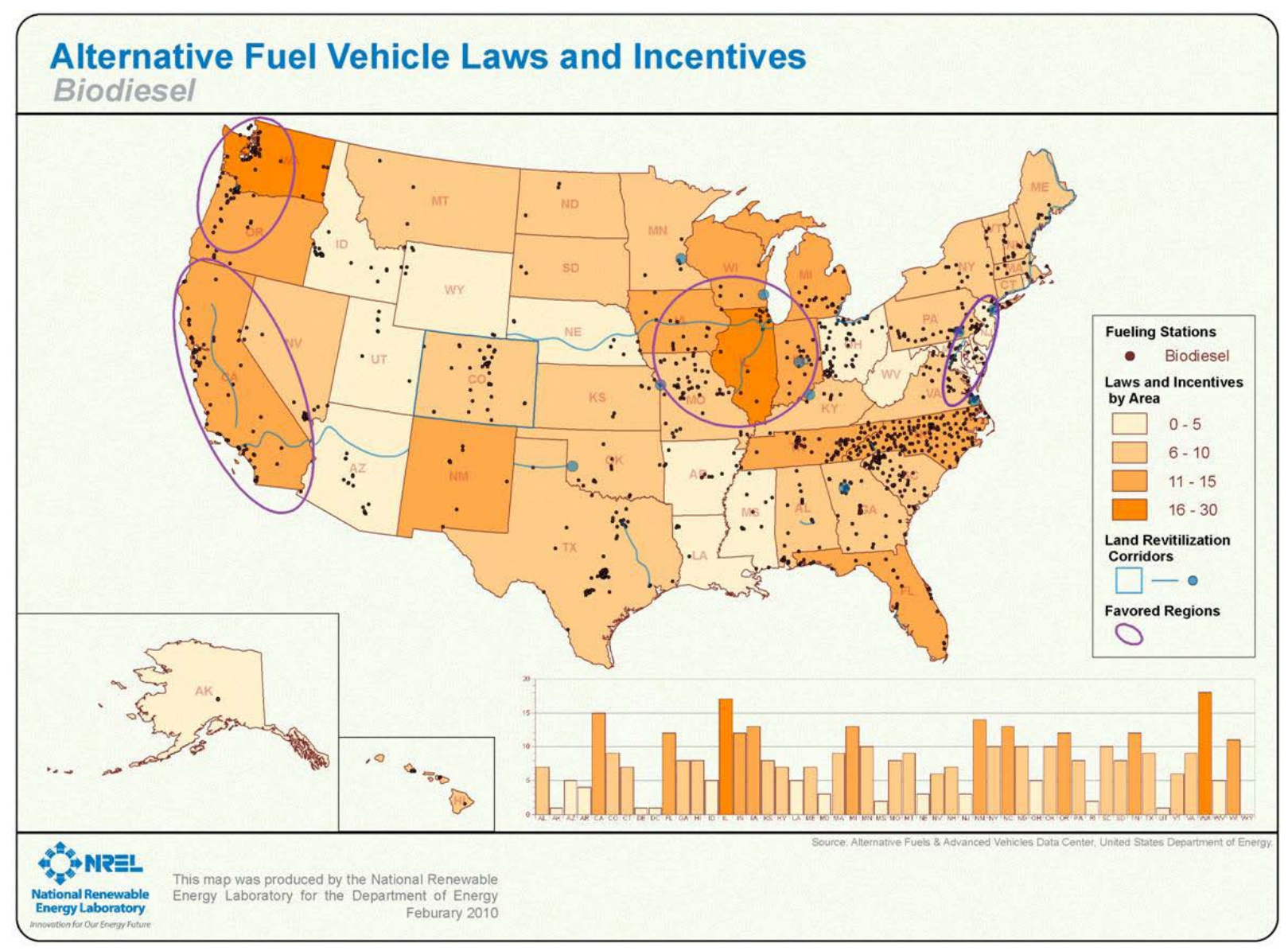

Figure 10. Biodiesel stations, land revitalization corridors, and state biodiesel incentives

\subsection{Alternative Fuel Summary}

Figures 3-10 highlight eight corridors as being an exceptional opportunity for at least one alternative fuel. As summarized in Table 7, the San Francisco-Los Angeles corridor was outstanding for all five alternative fuels, while Seattle-Eugene was exceptional for four. Chicago-Milwaukee was a prime choice for three fuels, and Highway 66 from Virginia to New York was great for two. These corridors would be exceptional locations for a multi-fuel program to convert former gasoline stations to sell alternative fuels. However, to illustrate the next phase of the site identification process, this report will specify one fuel.

Table 7. Exceptional Corridors by Fuel Type

\begin{tabular}{|c|c|c|c|c|c|}
\hline Region & Electricity & $\begin{array}{c}\text { Natural } \\
\text { Gas }\end{array}$ & Hydrogen & Ethanol & Biodiesel \\
\hline San Fran-Los Angeles & $\mathrm{X}$ & $\mathrm{X}$ & $\mathrm{X}$ & $\mathrm{X}$ & $\mathrm{X}$ \\
\hline Seattle-Eugene & $\mathrm{X}$ & $\mathrm{X}$ & - & $\mathrm{X}$ & $\mathrm{X}$ \\
\hline Chicago-Milwaukee & - & $\mathrm{X}$ & - & $\mathrm{X}$ & $\mathrm{X}$ \\
\hline VA-NY on Hwy 66 & - & $\mathrm{X}$ & - & - & $\mathrm{X}$ \\
\hline Hwy 41 in Florida & - & - & - & $\mathrm{X}$ & - \\
\hline
\end{tabular}




\section{Electric Charging Stations in the Seattle-Eugene Corridor}

This report uses electricity as the fuel with which to delve into the local strategy used to site a station. This is because, due to the current expansion in EV production, ${ }^{12}$ the large increase in research and development (R\&D) funds for EVs and batteries, ${ }^{13}$ the President's goal of 1 million EVs by $2015,{ }^{14}$ the shortage of current recharging infrastructure (only $8 \%$ of alternative refueling stations are EV charging sites ${ }^{15}$ ), and the limited range of EVs, EVs are arguably the largest opportunity for new "refueling" infrastructure. As shown in Table 4, the Seattle-Eugene corridor is one of the most promising locations to further investigate.

This section focuses on Level 2 (medium speed - explained in Section 7) electric charging stations in the Seattle-Eugene corridor and gives a checklist of how to determine the best specific sites. It does this through two case studies - Tacoma, Washington, and Albany, Oregon. Both case studies use the same checklist and start by identifying areas with many sites with leaking underground storage tanks (LUSTs), which include former gasoline stations. The 10 property characteristics on the checklist were developed to help prospective EV station owners determine what former gasoline station sites, or other similar sites, are most promising to convert to alternative fuel stations. The case studies highlight that not all items on the checklist need to be answered affirmatively in order for the site to be promising.

\subsection{Tools to Complete Checklist}

Five tools are available for site owners to assess their potential as an EV charging station. They are described below, and their use will be demonstrated in the next section's checklist.

1. GIS map seen in Figure 11. This map combines HEV populations, EV charging stations, EV focus sites, land revitalization corridors, and regional populations of LUSTs. Former gasoline stations are a subset of all LUSTs, and many non-gasoline station LUSTs were screened out, so the map of LUSTs is considered to be a good indicator of where there is a high concentration of former gasoline stations.

2. LUST sites. Attributes of a specific site, such as cleanup and ownership status, can be looked up on state environmental department websites. Washington's site is at https://fortress.wa.gov/ecy/tcpwebreporting/reports.aspx, and Oregon's is at www.deq.state.or.us/lq/tanks/lust/LustPublicLookup.asp.

3. AFDC alternative fuel station locator at www.afdc.energy.gov/afdc/locator/stations/. This locator allows one to enter the address of a site, and it will tell the distance to other refueling/recharging stations.

4. Google Maps "search nearby" function. To use this tool, site owners enter the address of the targeted site into Google Maps and enter "airport," "arena," "restaurant," "shopping," "gym," "school," "hotel," or other generalized commercial searches to find nearby

\footnotetext{
${ }^{12}$ Hsu, T. "GM to Increase Chevy Volt Production by 50\%." Los Angeles Times. July 31, 2010.

${ }^{13}$ White House. "President Obama Announces \$2.4 Billion in Grants to Accelerate the Manufacturing and Deployment of the Next Generation of U.S. Batteries and Electric Vehicles." White House press release. August 5, 2009.

${ }^{14}$ Voorhees, J. "Our Biggest Challenge is to Reinvent the Automobile." New York Times. July 10, 2009.

${ }^{15}$ U.S. Department of Energy. "Alternative Fueling Station Total Counts by State and Fuel Type." www.afdc.energy.gov/afdc/fuels/stations_counts.html. Accessed September 2010.
} 
commercial properties. Many federal properties (which are mandated to use alternative fuels) such as military bases and national forests automatically show up on the maps.

5. Google Maps's "street view" function. This tool allows anybody to view the current property and get an initial feel for if the planned route to nearby attractions is within walking distance while they wait for their EV to recharge.

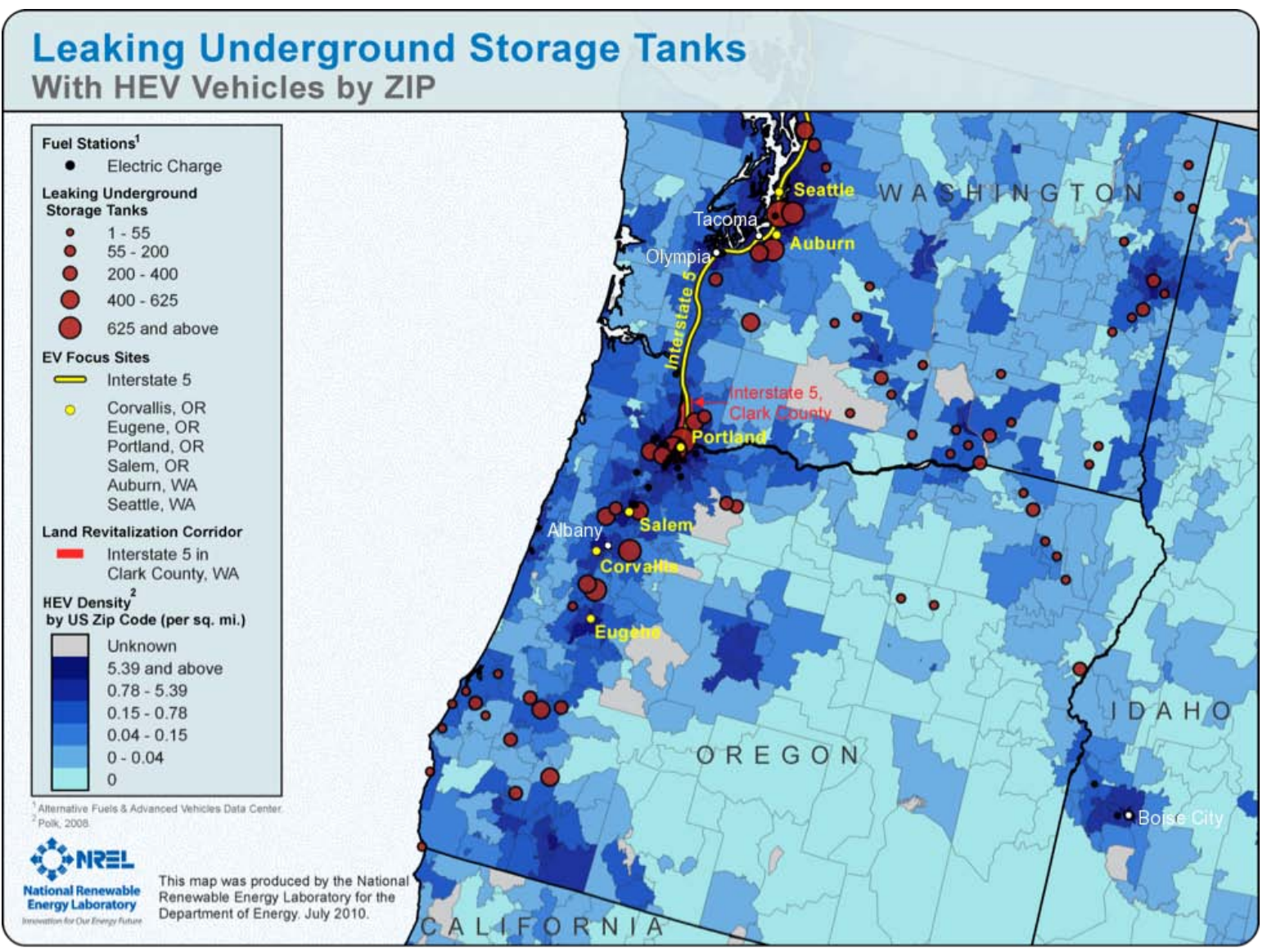

Figure 11. LUSTs, HEVs, EV focus sites, and land revitalization corridor along I-5 between Seattle, Washington, and Eugene, Oregon

\subsection{EV Case Study 1: Tacoma, Washington}

Case Study 1 demonstrates a search within the Seattle-Eugene corridor that found a site in Tacoma, Washington, to be a favorable location to add EV charging infrastructure. The site is a former Texaco gasoline station along Pacific Avenue. The checklist that revealed this as a favorable EV charging location is as follows:

1. Many LUST sites. The Tacoma area has many sites to choose from (between 400 and 625), which increases the odds that one of them will be in an ideal location and suitable for reuse (GIS map and state LUST websites).

2. High HEV density. Tacoma has a high density of HEVs, which indicates that the population is more likely to purchase EVs. Furthermore, it has high-density areas both 
north and south of the city on I-5. These areas are viewed as places for EV owners to charge their vehicles when travelling on I-5 (GIS map).

3. Proximity to other charging stations. Tacoma is approximately halfway between (and 20 miles from) the station at SeaTac airport and the four stations in Lacey/Olympia (GIS map and AFDC station locator).

4. Proximity to EV focus area. Tacoma is a short (14 mile) drive from Auburn, Washington, which received ARRA funding to put in charging stations and purchase EVs. Tacoma is five times the size of Auburn, so chances are great that many of Auburn's residents will travel to Tacoma for shopping and entertainment. During these times, EV owners are likely to use a charging station outside their homes. Many EV owners within the EV focus areas have charging stations installed at their homes, so in many cases it is better to install in a neighboring community (GIS map).

5. Close to major EV corridor road. The site is less than 0.5 mile from I-5 (GIS map and Google Maps).

6. Proximity to airport. Tacoma is approximately halfway between a station at SeaTac airport and four stations in the Olympia/Lacey area. Airports are good stations to anchor to because the demographics of people frequenting airports match those of the group deemed highly likely to purchase an EV. Furthermore, there is growing interest in rental car agencies to introduce EVs to their fleet, as evidenced by Enterprise's recent announcement to purchase 500 Nissan Leafs for use in Seattle and seven other cities, ${ }^{16}$ and rental fleets cluster around airports (Google Maps).

7. Proximity to federal fleet. Tacoma is only 12 miles from the Fort Lewis Army Base. As part of the federal government, the fort is mandated to purchase and use AFVs and already owns $23 \mathrm{EVs}^{17}$ (Google Maps).

8. Proximity to state fleet. Olympia is the capital of Washington and, therefore, garages many state vehicles. Much of their activity is in Seattle, and they need to travel through Tacoma to go between the two cities (Google Maps).

9. Walking distance to commercial area. The site is 0.4 miles from the Tacoma Dome, which should supply ample customers that will be parked for the length of one game. It is also within walking distance of numerous bars and restaurants that surround the stadium. In addition, it is one-third mile from the "Freighthouse Square," which has ample shops and is a key link between car traffic and rail traffic (Google Maps).

10. Station complements core business. A Google street view of the property shows an abandoned site. This means that EVSEs do not necessarily complement core business, but the owner could add infrastructure such as a convenience store or vending machines to increase profits (Google Maps).

\footnotetext{
${ }^{16}$ Smith, R.; Ramsey, M. "Rent a Leaf: Enterprise Buys a Fleet.” The Wall Street Journal. http://online.wsj.com/article/NA WSJ PUB:SB10001424052748704700404575391602609091276.html. Accessed March 7, 2011.

${ }^{17}$ Easley, M. "Fort Lewis: Seven Years of Sustainability." http://webcache.googleusercontent.com/search?q=cache:GayrB8GEOO8J:www.fedcenter.gov/ kd/go.cfm\%3Fdesti nation\%3DShowItem\%26Item _ID\%3D12658+Fort+Lewis+Electric + Vehicles\&cd=10\&hl=en\&ct=clnk\&gl=us. Accessed March 7, 2011.
} 
11. Station has space for alternative fuel station. Electric charging stations only require the space for the vehicle to park. Satellite and street-view images reveal that the property has room for many parking spaces (Google Maps).

12. Site can likely be cleaned for alternative fuel station quickly. The site has been in the "monitoring" phase of cleanup since December 2000, so the remaining effort to clean it up should be minimal (Washington LUST site).

\subsection{EV Case Study 2: Heritage Mall in Albany, Oregon}

The checklist that revealed this as a favorable EV charging location is as follows:

1. Many sites. This area has many sites to choose from (over 625), which increases the odds that one of them will be in an ideal location found suitable for reuse (GIS map).

2. High HEV density. Albany has a high HEV density, and it is strategically located between numerous other pockets of high density along I-5 and Highway 20 (GIS map).

3. Proximity to other charging stations. There is another public charging station in Albany, which indicates that there are already some local EVs. There is also one charging station 10 miles away in Corvallis and three more in Salem (21-26 miles away) (GIS map and AFDC locator).

4. Proximity to EV focus area. Albany is on I-5, which links six of the seven EV focus areas together. It also sits on Highway 20, which links Corvallis (the seventh focus area) to I5. While there could be funding and other incentives to install charging stations in a focus city, there will be less competition in places like Albany while having access to EVs from multiple focus areas (GIS map).

5. Close to major EV corridor road. The site is less than 1 mile from I-5 (GIS map and Google Maps).

6. Proximity to airport. Albany's airport is too small to consider when locating an EV station (Google Maps).

7. Proximity to federal fleet. Albany is within 100 miles of Willamette, Deschutes, Umpqua, Suislaw, and Mt. Hood National Forests. All national forest fleets are mandated to purchase AFVs and to reduce their petroleum use. Albany's central location between these national forests makes it a logical place to recharge when traveling between them (Google Maps).

8. Proximity to state fleet. Albany is 26 miles from Salem, the state capital, where many of the state fleets are garaged. State fleets, like federal fleets, are mandated to purchase AFVs and use alternative fuel (Google Maps).

9. Walking distance to commercial area. The site is 0.25 mile from Heritage Mall (Google Maps).

10. Station complements core business. The site is shared with an auto parts store, so this is a logical match. 
11. Station has space for alternative fuel station. Electric charging stations only require the space for the vehicle to park. Satellite and street-view images reveal that the property has 20 parking spaces (Google Maps).

12. Site can likely be cleaned for alternative fuel station quickly. The site has been in the "monitoring" phase of cleanup since at least June 2008 (Oregon LUST site). 


\section{Choosing and Installing EV Charging Equipment}

Once it is determined that a former gasoline station site is in a favorable location for an EV charging station, the next step is to find the most appropriate equipment and installers. Prospective station owners will not be alone during this process, as it is recommended and required that they collaborate with a number of parties. These parties, shown as the inner six boxes in Figure 12, make the numbered tasks on the outside of the figure much more manageable. This figure comes from the DOE-sponsored EV Charging Infrastructure Deployment Guidelines, ${ }^{18}$ which is a thorough and highly recommended guide. These guides were done for a number of regions throughout the nation, including one for Oregon ${ }^{19}$ and one for greater Seattle. $^{20}$ These guides enable the proper installation of EVSE. Their key goals, as they pertain to prospective station owners, are listed in the following sections.

\footnotetext{
18 eTEC. "Electric Vehicle Charging Infrastructure Deployment Guidelines Series.” www.theevproject.com. Accessed April 2011.

${ }^{19}$ eTEC. "Electric Vehicle Charging Infrastructure Deployment Guidelines for the Oregon I-5 Metro Areas of Portland, Salem, Corvallis, and Eugene." www.oregon.gov/ODOT/HWY/OIPP/docs/EVDeployGuidelines31.pdf?ga=t. Accessed April 21, 2011.

${ }_{20}$ eTEC. "Electric Vehicle Charging Infrastructure Deployment Guidelines for the Central Puget Sound Area." www.theevproject.com/downloads/documents/Central $\% 20$ Puget $\% 20$ Sound $\% 20 \% 20 \mathrm{EV} \% 20$ Infrastructure $\% 20 \mathrm{Guid}$ elines\%20Ver\%203-1.pdf. Accessed April 21, 2011.
} 


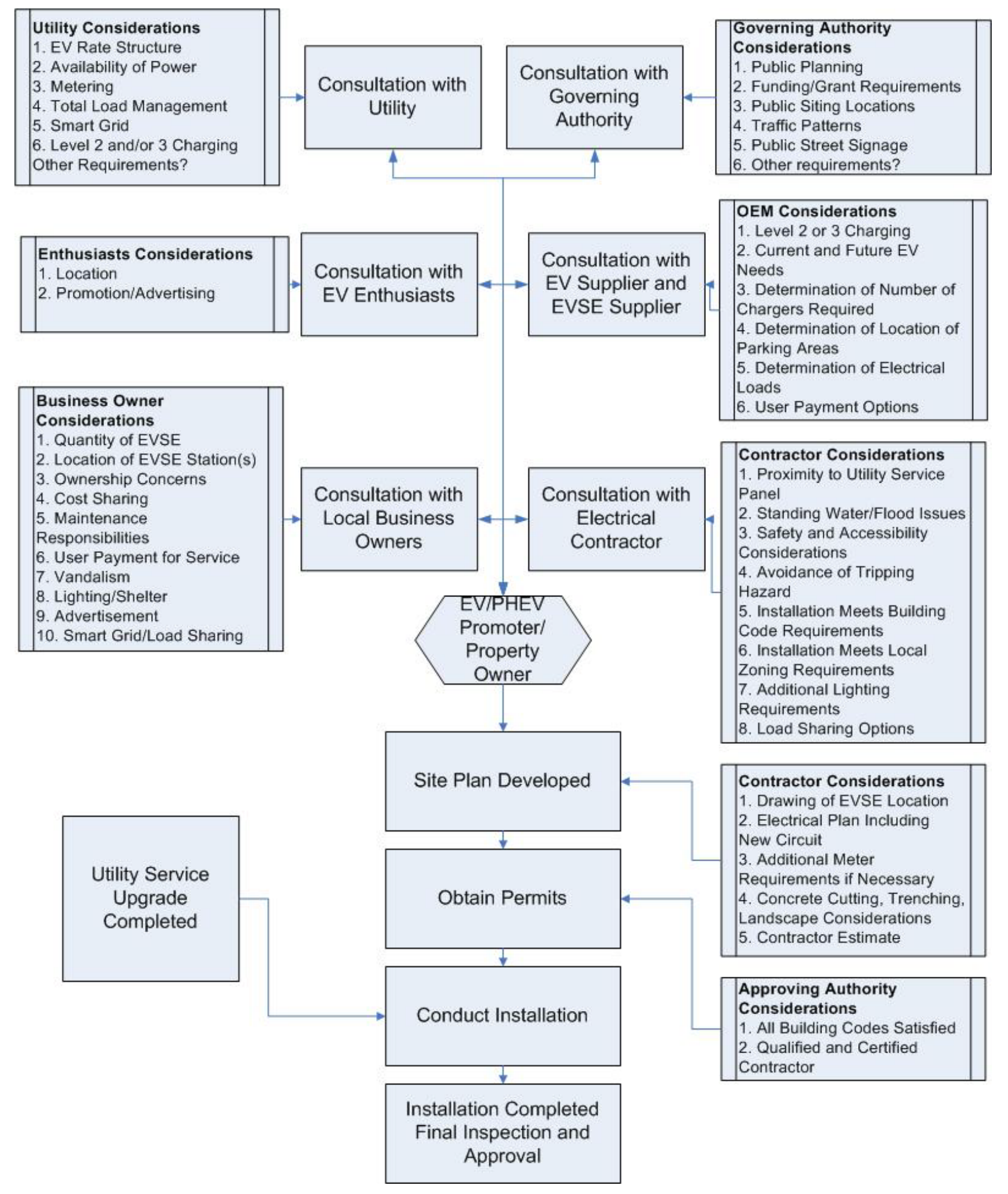

Figure 12. Installation flowchart for public charging

Source: eTEC 2010, Electric Vehicle Charging Infrastructure Guidelines 


\subsection{Choosing EVSE}

EVSE includes the equipment between the utility power and the vehicle. EVSEs usually include an interface (plug) to the utility power and a control device, cord, and connector to the vehicle. Thanks to the Society of Automotive Engineers, the connector will now be the same no matter what EV you are charging. ${ }^{21}$ This is because their new standard J1772 calls for all Level 1 and 2 connectors to use a connector with five pins - two alternating current (AC) power, one ground, one communication line, and one proximity detection pin that disables the car while plugged in.

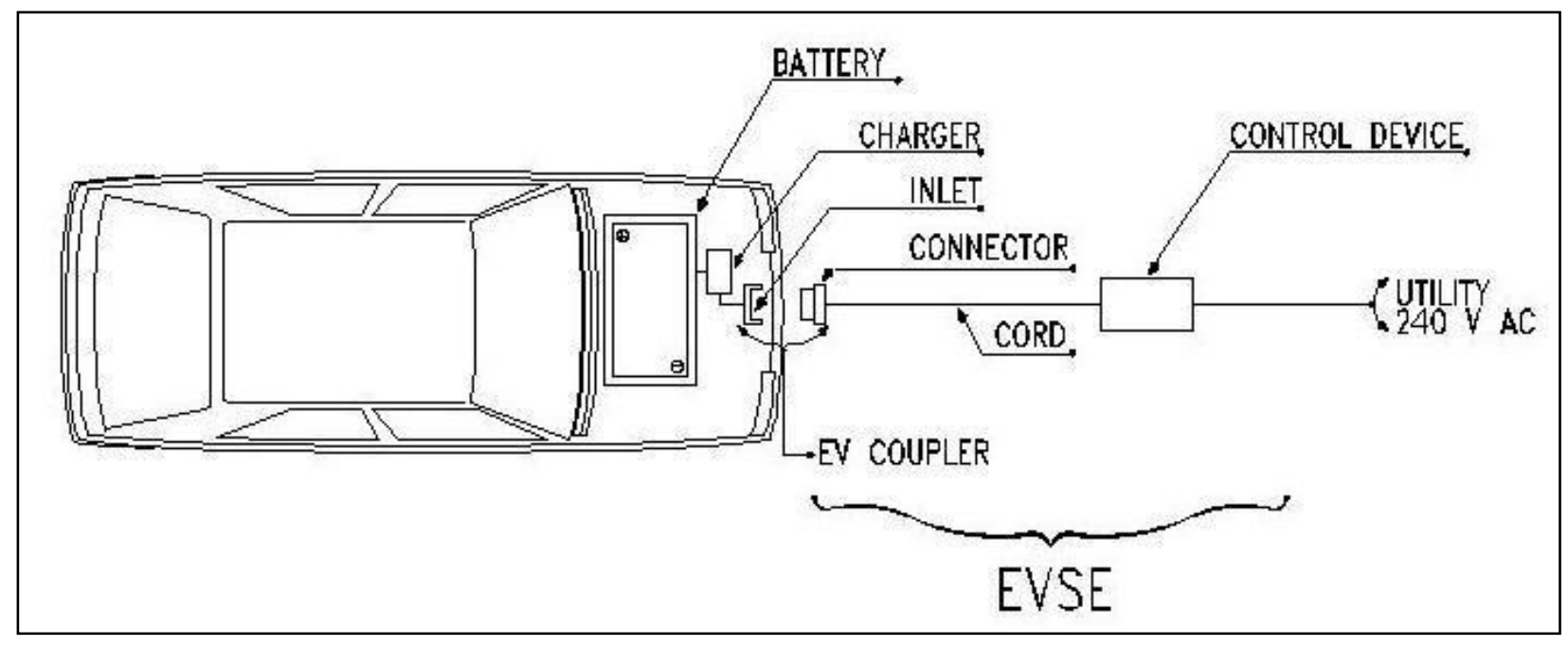

Figure 13. Level 2 charging diagram

Source: eTEC 2010

Different EVSEs take different amounts of time to deliver a full charge to the battery. These chargers are grouped by levels described below. Station owners must be cognizant of the amount of time they expect a vehicle to be plugged in. Level 2 EVSE is currently the closest to fitting the needs of the EV drivers that will charge their cars at the type of sites identified in this report. Costs and times cited below are from eTEC 2010, but these costs are highly dependent on specific project conditions and are rapidly changing. For current EVSE costs (pre-installation), please visit www.pluginamerica.org/accessories.

1. Level 1 EVSE delivers $120 \mathrm{~V}$ electricity, similar to most other outlets. This is inexpensive and very easy to install but takes a long time (15 hours for an EV or 10 for a PHEV) to charge a battery. These EVSEs are recommended for homes, hotels, airports, and places of work.

2. Level 2 EVSE is the recommended equipment for the purpose of this report because its refueling window is less than a Level 1 and its expense is less than a Level 3 EVSE. It delivers $240 \mathrm{~V}$ electricity, so it requires the same wiring as a clothes dryer. A typical installation of two public Level 2 EVSEs costs $\$ 15,000-\$ 18,000$ and can fully charge common EVs in 3 hours 40 minutes or PHEVs in 2.5 hours. This charging time makes it ideal for the EVs targeted by this report: shoppers, restaurant diners, and people out being entertained.

\footnotetext{
${ }^{21}$ SAE International. "SAE Electric Vehicle and Plug in Hybrid Electric Vehicle Conductive Charge Coupler." http://standards.sae.org/j1772_201001/. Accessed April 2011.
} 
3. Level 3 EVSE should be used strategically to satisfy EVs that do not have much time to charge. These are appropriate in places like convenience stores and coffee shops. Station owners want to minimize the number of these because they are expensive and their useful life is unproven since standards have not yet been announced for them. Level 3 EVSEs include a converter so they can provide direct current (DC) to the vehicle. These EVSEs require a dedicated breaker and special grounding equipment, which drives the costs up. A typical installation of two public Level 3 EVSEs costs $\$ 65,000-\$ 70,000$, but there are major economies of scale if more are added. The advantage of Level 3 EVSEs is that they are fast - 20-40 minutes for a full charge on an EV and 20 minutes for a PHEV. Keep in mind that partial charges are often all that would be needed for a vehicle to get home, so charging just a few minutes at a Level 3 station has great value. In the future, fast charging could draw many customers to fast-turnover businesses such as convenience stores and coffee shops.

Prospective station owners should ask their utility for recommendations for electrical contractors and EVSE suppliers. They should also ask recommended electrical contractors what EVSE suppliers they prefer and vice versa. There is no list of electrical contractors that specialize in EVSE installation, but Plugin Recharge is maintaining a list of EVSE suppliers at www.pluginrecharge.com/p/evse-vendors.html.

\subsection{Installing EVSE}

The electrical contractor should develop a site plan showing all electrical equipment, where the EVSE will be located, parking spaces, and more. The contractor should be able to interface with the utility to ensure the proper upgrade of utility service. The contractor should also use the site plan to obtain all necessary permits from the approving authority.

There are three considerations that are sometimes outside the purview of electrical contractors. First, the electrical cord is a substantial tripping hazard that needs to be mitigated by proper placement of the control device. Second, assessments on where water will run or stand in a major storm should be done to ensure that the EV will never be charged while standing in water. Finally, precautions such as proper lighting should be taken to ensure the safety of the EVSE (against vandals) and the clients.

\subsection{Paying for EVSE}

The Alternative Fuel Infrastructure Tax Credit reimburses $30 \%$ of the cost of all EVSEs, up to $\$ 30,000$. More can be read about this tax credit and similar credits offered by state governments at the AFDC Incentives and Laws database. ${ }^{22}$ The utility can discuss options of tracking the amount of electricity passed through the EVSEs and various payment options, such as time-ofuse pricing, available to large electricity customers.

\subsection{Connecting to Adequate Power Supply}

The utility can inform the electrical contractor of the site's capacity and how many EVSEs they can support as well as help them upgrade their service. This is especially important if the site plans to install a Level 3 EVSE, if they plan numerous Level 2 EVSEs, or if they are in a residential neighborhood (as opposed to commercial).

\footnotetext{
${ }^{22}$ U.S. Department of Energy. "Federal \& State Incentives \& Laws.” www.afdc.energy.gov/afdc/laws/. Accessed
} April 2011. 


\subsection{Obtaining Permits}

Permits should be coordinated by the electrical contractor. In Washington, the permitting authority is Labor \& Industries, and in Oregon, it is the Building Codes Division (BCD) of the state government. To expedite the process, $\mathrm{BCD}$ has instated an e-permitting program that is available in most of the Oregon areas designated in this report as EV focus areas.

\subsection{Drawing Adequate Customer Supply}

If the checklist to identify a favorable site for EVSE is used properly, the site should be well positioned to attract the first wave of EV owners. However, proper signage at the station has been shown to be very important to the sales of other alternative fuels. ${ }^{23}$ If patterns from other alternative fuels apply to EVs, it would also behoove the charging station to inform EV purchasers of their station location in the following ways:

1. Offer pamphlets (with a map) to EV purchasers at nearby dealerships

2. Inform the $\mathrm{AFDC}^{24}$ so they can include the station in the alternative fuel locator

3. Hold a grand-opening event with a promotional deal to make the site known

4. Advertise the merits of EVs along with the site location via road signs and radio advertisements.

\footnotetext{
${ }^{23}$ Bromiley, P.; Gerlach, T.; Marczak, K.; Taylor, M.; Dobrovolny, L. Statistical Analysis of the Factors Influencing Consumer Use of E85. NREL/SR-540-42984. Golden, CO: National Renewable Energy Laboratory, July 2008.

${ }^{24}$ Contact AFDC by e-mail at technicalresponse@icfi.com.
} 


\section{Conclusion}

Communities with former gasoline station sites may be in need of a profitable use of their land just as the push for alternative fuels is in need of locations for their refueling stations. This can be a fortuitous transition if the site is in the right location and has the right attributes for a given fuel. Based on corridors where land revitalization efforts are underway, local efforts to promote alternative fuels, current alternative fuel infrastructure, gasoline prices, AFV locations, incentives at the state level, and environmental benefits, a few regions of the country appear to be great candidates for converting petroleum brownfields to alternative fuel stations. The most favorable of these regions are Highway 99 from San Francisco to Los Angeles; the I-5 Corridor from Seattle, Washington, to Eugene, Oregon; the greater Chicago-Milwaukee area with expansion through Illinois, Iowa, and Wisconsin; and Route 1 from Quantico, Virginia, through New York.

Under closer investigation, the EV recharging infrastructure in the I-5 corridor proved to be a very promising niche of petroleum brownfield conversions. The LUST sites in this area, which include former gasoline stations, were mapped along with features that indicate EV traffic to enable prospective EV station owners the ability to assess the potential of converting specific sites. A checklist was presented to enable thorough evaluation of a site along with a set of tools to aid in this evaluation. Guidelines were then laid out for what a prospective station owner in the Seattle-Eugene corridor needs to do to convert a former gasoline station site to charge EVs, which may decrease the number of unproductive petroleum brownfield sites by increasing the number of productive alternative fuel stations. This conversion would result in improved land use, reduced GHG emissions, and reduced independence on foreign oil. 